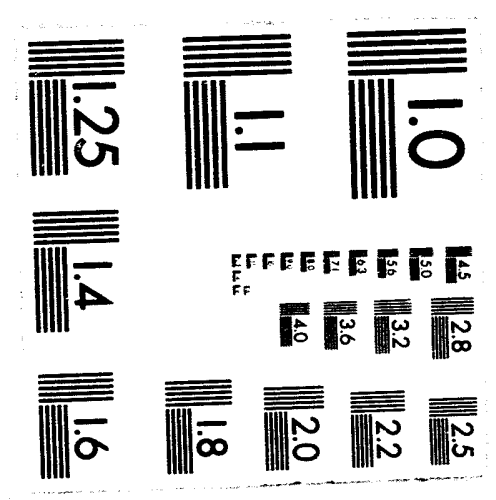



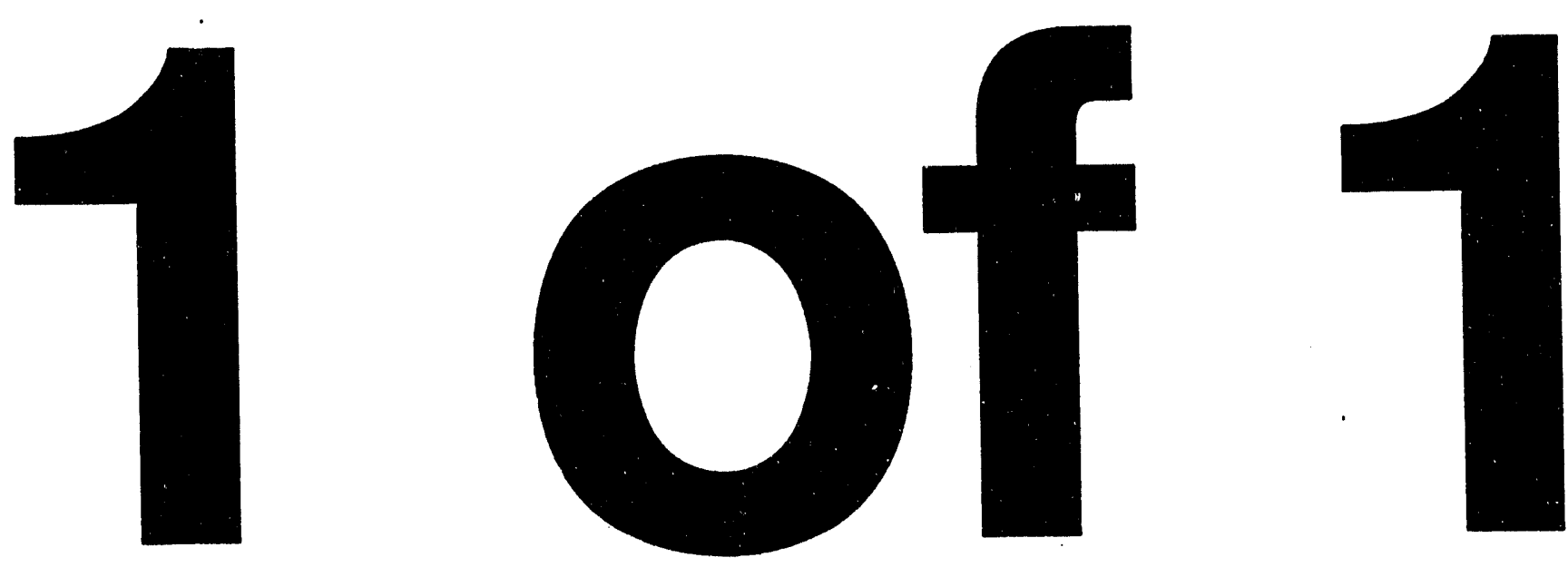

• 
NUREG/CR-6077

ORNL/TM-12416

\section{Data Summary Report for \\ Fission Product Release Test VI-6}

Manuscript Completed: February 1994

Date Published: March 1994

Prepared by

M. F. Osborne, R. A. Lorenz, J. R. Travis, C. S. Webster,

J. L. Collins

Oak Ridge National Laboratory

Operated by Martin Marietta Energy Systems, Inc.

Oak Ridge National Laboratory

Oak Ridge, TN 37831-6050

\section{Prepared for}

Division of Systems Research

Office of Nuclear Regulatory Research

U.S. Nuclear Regulatory Commission

Washington, DC 20555-0001

NRC FIN B0127

Under Contract No. DE-AC05-840R21400 


\section{Abstract}

Test VI-6 was the sixth test in the VI series conducted in the vertical furnace. The fuel specimen was a 15.2cm-long section of a fuel rod from the BR3 reactor in Belgium. The fuel had experienced a burnup of $\sim 42 \mathrm{MWd} / \mathrm{kg}$, with inert gas release during irradiation of $\sim 2 \%$. The fuel specimen was heated in an induction furnace at $2300 \mathrm{~K}$ for $60 \mathrm{~min}$, initially in hydrogen, then in a steam atmosphere. The released fission products were collected in three sequentially operated collection trains designed to facilitate sampling and analysis.

The fission product inventories in the fuel were measured directly by gamma-ray spectrometry, where possible, and were calculated by ORIGEN2. Integral releases were $75 \%$ for ${ }^{85} \mathrm{Kr}, 67 \%$ for ${ }^{129} \mathrm{I}, 64 \%$ for ${ }^{125} \mathrm{Sb}$, $80 \%$ for both ${ }^{134} \mathrm{Cs}$ and ${ }^{137} \mathrm{Cs}, 14 \%$ for ${ }^{134} \mathrm{Eu}, 63 \%$ for $\mathrm{Te}, 32 \%$ for $\mathrm{Ba}, \mathbf{1 3 \%}$ for $\mathrm{Mo}$, and $5.8 \%$ for $\mathrm{Sr}$. Of the totals released from the fuel, $43 \%$ of the Cs, $32 \%$ of the $\mathrm{Sb}$, and $98 \%$ of the Eu were deposited in the outlet end of the furnace. During the heatup in hydrogen, the ircaloy cladding melted, ran down, and reacted with some of the $\mathrm{UO}_{2}$ and fission products, especially $\mathrm{Te}$ and $\mathrm{Sb}$. The total mass released from the furnace to the collection system, including fission products, fuel, and structural materials, was $0.57 \mathrm{~g}$, almost equally divided between thermal gradient tubes and filters. The release behaviors for the most volatile elements, $\mathrm{Kr}$ and $\mathrm{Cs}$, were in good agreement with the ORNL Diffusion Model. 


\section{Contents}

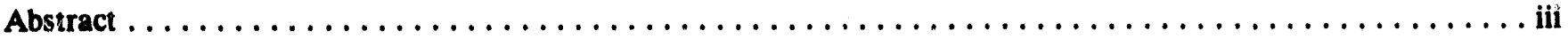

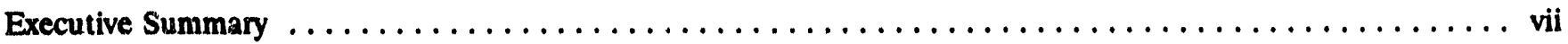

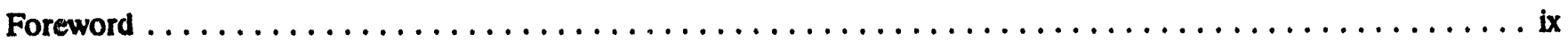

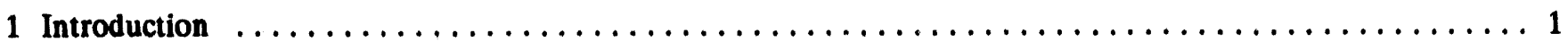

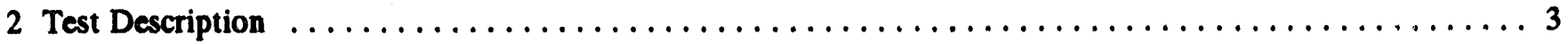

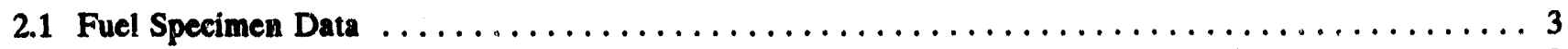

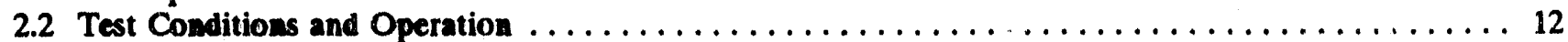

2.3 Posttest Disacembly and Examination $\ldots \ldots \ldots \ldots \ldots \ldots \ldots \ldots \ldots \ldots \ldots \ldots \ldots \ldots \ldots$

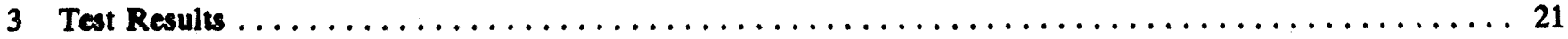

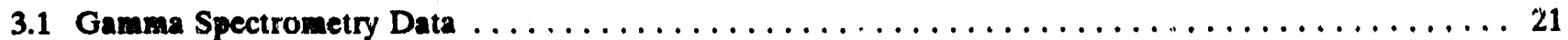

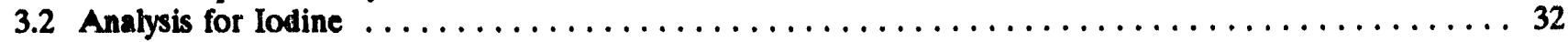

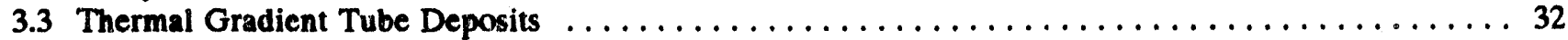

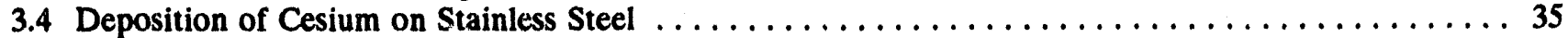

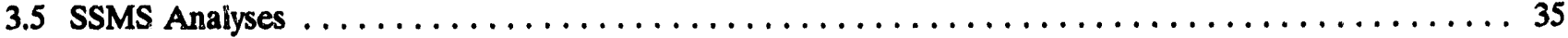

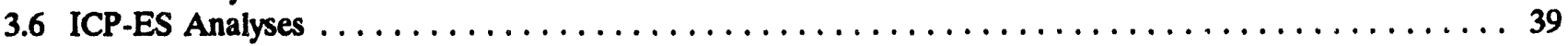

4 Comparison of Release Data with Previous Results $\ldots \ldots \ldots \ldots \ldots \ldots \ldots \ldots \ldots \ldots \ldots \ldots$

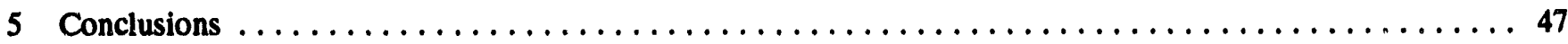

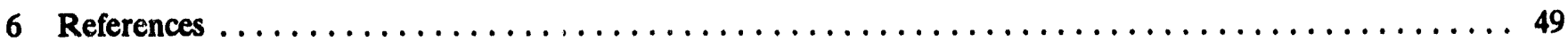

Figures

2.1 Vertical fission product release furnace, as used in test VI-6 $\ldots \ldots \ldots \ldots \ldots \ldots \ldots \ldots \ldots \ldots$

2.2 Vertical fission product release apparatus $\ldots \ldots \ldots \ldots \ldots \ldots \ldots \ldots \ldots \ldots \ldots \ldots \ldots \ldots$

2.3 Components of the fission product collection system $\ldots \ldots \ldots \ldots \ldots \ldots \ldots \ldots \ldots \ldots \ldots \ldots$

2.4 Details of the fuel specimen heated in test VI-6 $\ldots \ldots \ldots \ldots \ldots \ldots \ldots \ldots \ldots \ldots \ldots \ldots \ldots$

2.5 In-reactor release of gaseous fission products as a function of power. The gas inside rods I-830 and I-887 was measured before sectioning $\ldots \ldots \ldots \ldots \ldots \ldots \ldots \ldots \ldots \ldots \ldots \ldots \ldots \ldots \ldots \ldots$

2.6 Pretest gamma scan, using a $0.25-\mathrm{mm}$ window, of the test VI-6 fuel specimen. Note uniform fuel burnup

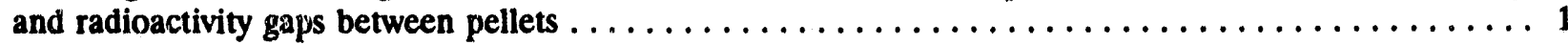

2.7 Distribution of ${ }^{134} \mathrm{Cs},{ }^{137} \mathrm{Cs}$, and ${ }^{154} \mathrm{Eu}$ in the fuel and for ${ }^{60} \mathrm{Co}$ in the cladding of the test VI-6 fuel

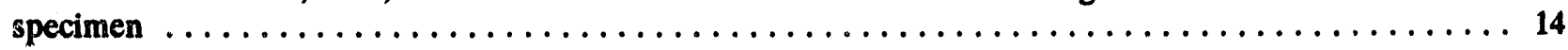

2.8 Temperature and collection period history for test VI-6 $\ldots \ldots \ldots \ldots \ldots \ldots \ldots \ldots \ldots \ldots \ldots$

2.9 Top view of open furnace after test VI-6, showing top of fuel specimen tilted to side $\ldots \ldots \ldots \ldots \ldots 19$

3.1 Distributions of fission product ${ }^{106} \mathrm{Ru},{ }^{137} \mathrm{Cs}$, and ${ }^{154} \mathrm{Eu}$ in the fuel-furnace tube assembly after test VI-6 .. 22 
3.2 Distribution of ${ }^{105} \mathrm{Ru},{ }^{125} \mathrm{Sb}$, and ${ }^{60} \mathrm{Co}$ in the fuel-furnace tube assembly after test VI-6 . . . . . . 23

3.3 Release behavior of ${ }^{85} \mathrm{Kr}$ vs $t_{1}$, ne and temperature in test $\mathrm{VI}-6 \ldots \ldots \ldots \ldots \ldots \ldots \ldots \ldots \ldots \ldots$

3.4 Release behavior of ${ }^{137} \mathrm{Cs}$ from fuel during test VI-6, as indicated by detectors monitoring top and bottom

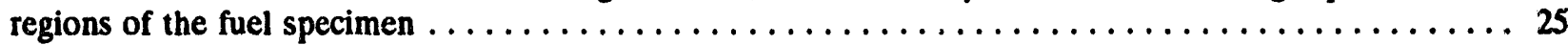

3.5 On-line distribution of released cesium fol .2s, vapor to TGTs and aerosol to filters, compared to krypton

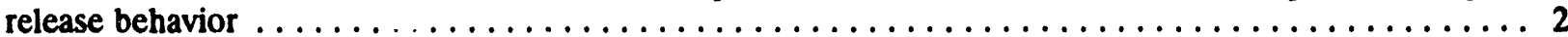

3.6 Distributions of ${ }^{137} \mathrm{Cs}$ along thermal gradient tubes $\mathrm{A}, \mathrm{B}$, and $\mathrm{C}$ in test VI-6. Note temperature

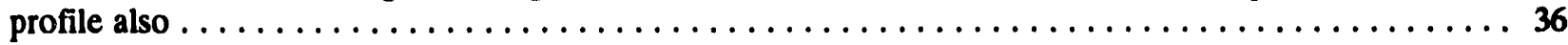

3.7 Mass distribution to the collection system of material released during test VI-6 $\ldots \ldots \ldots \ldots \ldots$

3.8 Diffusion coefficients for ${ }^{85} \mathrm{Kr}$, as calculated from minute-by-minute release data, in test VI-6. Note decline in diffusion coefficients with source depletion at test temperature $(2310 \mathrm{~K}) \ldots \ldots \ldots \ldots$

3.9 Diffusion coefficients for ${ }^{85} \mathrm{Kr}$ at constant test temperature $(2310 \mathrm{~K})$ in test VI-6 $\ldots \ldots \ldots \ldots \ldots$

4.1 Total release fractions for $\mathrm{Kr}, \mathrm{Cs}, \mathrm{Ba}, \mathrm{Te}, \mathrm{Sb}, \mathrm{Eu}$, and Mo during the three phases of test VI-6 . . . . 45

Tables

1.1 Analytical techniques used for fission product analysis $\ldots \ldots \ldots \ldots \ldots \ldots \ldots \ldots \ldots \ldots \ldots \ldots$

2.1 Data for fuel specimen used in test VI-6 $\ldots \ldots \ldots \ldots \ldots \ldots \ldots \ldots \ldots \ldots \ldots \ldots \ldots \ldots$

2.2 Fission product and actinide inventories in test VI-6: nuclides $\ldots \ldots \ldots \ldots \ldots \ldots \ldots \ldots \ldots$

2.3 Fission product and actinide inventories in test VI-6: elements $\ldots \ldots \ldots \ldots \ldots \ldots \ldots \ldots \ldots$

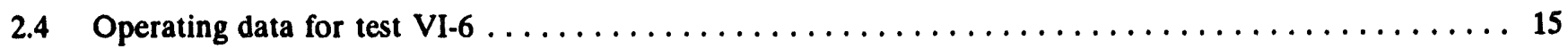

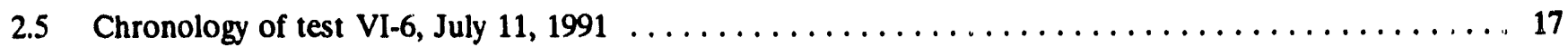

3.1 Summary of fission product release data for test VI- $6 \ldots \ldots \ldots \ldots \ldots \ldots \ldots \ldots \ldots \ldots \ldots$

3.2 Cesium release and distribution data for test VI- $6 \ldots \ldots \ldots \ldots \ldots \ldots \ldots \ldots \ldots \ldots \ldots$

3.3 Retention in furnace of cesium released from fuel in VI tests $\ldots \ldots \ldots \ldots \ldots \ldots \ldots \ldots \ldots$

3.4 Fractional release and distribution of antimony and europium in test VI-6 $\ldots \ldots \ldots \ldots \ldots \ldots$

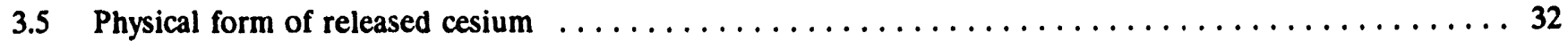

3.6 Iodine release and distribution data for test VI $-6 \ldots \ldots \ldots \ldots \ldots \ldots \ldots \ldots \ldots \ldots \ldots \ldots \ldots \ldots$

3.7 Comparison of physical forms of iodine and cesium released to collection trains $\ldots \ldots \ldots \ldots \ldots \ldots$

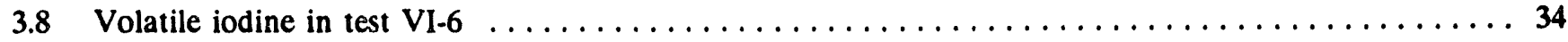

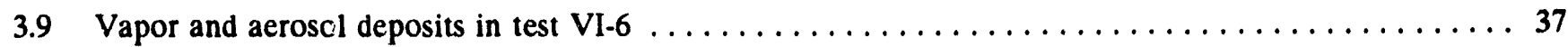

3.10 Test VI-6 release data for less-volatile fission products $\ldots \ldots \ldots \ldots \ldots \ldots \ldots \ldots \ldots \ldots \ldots \ldots$

4.1 Comparison of fission product release data for VI tests $\ldots \ldots \ldots \ldots \ldots \ldots \ldots \ldots \ldots \ldots$ NUREG/CR-6077 vi 


\section{Executive Summary}

The objective of this report is to document as completely as possible the observations and results of fission product release test VI-6 that was performed July 11, 199i. Although all analyses have not been completed and all final data have not been received, this report presents all currently available results for potential use by other reactor safety researchers. Complete interpretation and correlation of these results with related experiments and with theoretical behavior will be included in subsequent reports, which will consider the results of several tests over a range of test conditions. Similar data summary reports for previous tests in this project, as well as other reports of related project activities, are listed in the Foreword.

The fuel specimen used in this test was cut from fuel rod I-114 that had been irradiated in the BR3 reactor in Belgium from July 15, 1976, to September 26, 1980. The specimen contained $71.80 \mathrm{~g}$ uranium and had been irradiated to a burnup of $\sim 42 \mathrm{MWd} / \mathrm{kg}$ uranium. The fission product inventories, as measured in the fuel and calculated by ORIGEN2, and a description of the test procedure and conditions are included in Section 3. This test was heated to the test temperature $(2300 \mathrm{~K})$ in a hydrogen-helium atmosphere; the Zircaloy cladding melted and ran down the vertical specimen, exposing the $\mathrm{UO}_{2}$ fuel pellets. The hydrogen flow was then replaced with steam, which began to oxidize the $\mathrm{UO}_{2}$. The objective of the test was to determine the effect of steam oxidation on fission product release and transport. The test results and some preliminary interpretations are presented in Section 4, and these results are compared with data from previous tests in Section 5. The most important results are:

(1) Posttest examination, in agreement with on-line radioactivity measurements, indicated that the Zircaloy cladding had melted during the 'est. The 15-cm-long fuel specimen apparently had not collapsed, however, but remained standing throughout the test.

(2) The values for total fractional release from the fuel specimen, based on ORIGEN2 calculations and gamma-ray spectrometry measurements, were $\sim 75 \%$ for ${ }^{85} \mathrm{Kr}, 64 \%$ for ${ }^{125} \mathrm{Sb}, 80 \%$ for both ${ }^{134} \mathrm{Cs}$ and ${ }^{137} \mathrm{Cs}$, and $14 \%$ for ${ }^{154} \mathrm{Eu}$. Other measurement techniques showed that $67 \%$ of the ${ }^{129} \mathrm{I}, 63 \%$ of the $\mathrm{Te}, 32 \%$ of the $\mathrm{Ba}, 13 \%$ of the $\mathrm{Mo}$, and $5.8 \%$ of the $\mathrm{Sr}$ were released also. About $32 \%$ of the released ${ }^{125} \mathrm{Sb}, 35 \%$ of the released ${ }^{129} \mathrm{I}, 54 \%$ of the released Cs, and $98 \%$ of the released ${ }^{154} \mathrm{Eu}$ were deposited on the $\mathrm{ZrO}_{2}$ ceramics at the outlet end of the furnace. Pretest and posttest gamma-ray spectrometry of the fuel was valuable in determining the release fractions as well as the axial distributions of the fission products within the fuel rod and the furnace.

(3) Compared to earlier tests, both in steam (VI-1, -2 , and -3 ) and in hydrogen (VI-4 and -5), a larger fraction of the cesium released in test VI-6 (54\% vs 4 to $47 \%$ ) deposited on components in the exit (top) end of the furnace. In addition, the amounts of released cesium in vapor $(43 \mathrm{mg}$ ) and aerosol $(37 \mathrm{mg}$ ) forms, as indicated by collection in the thermal gradient tubes (TGTs) and filters, respectively, were nearly the same in test VI-6.

(4) The axial distributions of cesium in the test VI-6 TGTs were more uniform than in most previous tests. In TGT A (which was used during Test Phase A - the initial part of the test), a tall narrow peak indicated a high concentration of cesium at a deposition temperature of $\sim 350^{\circ} \mathrm{C}$ $(\sim 625 \mathrm{~K})$. No other radionuclides were detected in the TGTs except for small concentrations of ${ }^{125} \mathrm{Sb}$ and ${ }^{154} \mathrm{Eu}$, both near the entrance of TGT $\mathrm{C}$, used during Test Phase $C$, the final $40 \mathrm{~min}$ of the test.

(5) The total mass of deposits on the TGTs and filters was deternined by direct weighing to be $0.57 \mathrm{~g}$; this mass was almost equally divided between the TGTs and the filters, but most of the release occurred during Test Phase $C$. It should be noted that the test configuration did not include reactor structural or control materials which could add significant aerosol masses during an accident.

(6) Approximately $5.1 \%$ of the released iodine was collected in a volatile form, $\mathrm{I}_{2}, \mathrm{HI}$, or $\mathrm{CH}_{3} \mathrm{I}$. This relatively high fraction - in most previous tests, $<0.5 \%$ of the iodine was found at this location is believed to result from radiation decomposition of more stable forms, such as CsI.

(7) The measured diffusion coefficients for the release of ${ }^{85} \mathrm{Kr}$ and ${ }^{137} \mathrm{Cs}$ agreed well with the ORNL Diffusion Release Model. 


\section{Foreword}

This document describes the sixth test in the VI series of fission product release tests of high-burnup, commercial LWR fuel under severe accident conditions. Similar tests at somewhat lower temperatures were conducted in the previous $\mathrm{HI}$ series. Other ORNL reports describing the work conducted for this project are listed below.

1. M. F. Cisborne, R. A. Lorenz, J. R. Travis, and C. S. Webster, "Data Summary Report for Fission Product Release Test HI-1," NUREG/CR-2928 (ORNL/TM-8500), December 1982.

2. M. F. Osborne, R. A. Lorenz, J. R. Travis, C. S. Webster, and K. S. Norwood, "Data Summary Report for Fission Product Release Test HI-2," NUREG/CR-3171 (ORNL/TM-8667), April 1984.

3. M. F. Osborne, R. A. Lorenz, K. S. Norwood, J. R. Travis, and C. S Webster, "Data Summary Report for Fission Product Release Test HI-3," NUREG/CR-3335 (ORNL/TM-8793), April 1984.

4. M. F. Osborne, J. L. Collins, R. A. Lorenz, K. S. Norwood, J. R. Travis, and C. S. Webster, "Data Summary Report for Fission Product Release Test HI-4," NUREG/CR-3600 (ORNL/ TM-9001), June 1984.

5. M. F. Osborne, J. L. Collins, R. A. Lorenz, K. S. Norwood, J. R. Travis, and C. S. Webster, "Data Summary Report for Fission Product Release Test HI-5," NUREG/CR-4037 (ORNL/ TM-9437), May 1985.

6. M. F. Osborne, J. L. Collins, R. A. Lorenz, K. S. Nonwood, J. R. Travis, and C. S. Webster, "Data Summary Report for Fission Product Release Test HI-6," NUREG/CR-4043 (ORNL/ TM-9943), September 1985.

7. M. F. Osborne, J. L. Collins, R. A. Lorenz, J. R. Travis, and C. S. Webster, "Desighi, Construction, and Testing of a $2000^{\circ} \mathrm{C}$ Furnace and Fission Product Collection System," NUREG/ CR-3715 (ORNL/TM-9135), September 1984.
8. J. L. Collins, M. F. Osborne, R. A. Lorenz, K. S. Norwood, J. R. Travis, and C. S. Webster, "Observed Behavior of Cesium, lodine, and Tellurium in the ORNL Fission Product Release Program," NUREG/CR-3930 (ORNL/TM-9316), February 1985.

9. K. S. Norwood, "An Assessment of Thermal Gradient Tube Results from the HI Series of Fission Product Release Tests," NUREG/CR-4105 (ORNL/TM-9506), March 1985.

10. M. F. Osborne, J. L. Collins, P. A. Haas, R. A. Lorenz, J. R. Travis, and C. S. Webster, "Design and Final Safety Analysis Report for Vertical Furnace Fission Product Release Apparatus in Hot Ccll B, Building 4501," NUREG/CR-4332 (ORNL/TM-9720), March 1986.

11. M. F. Osborne, J. L. Collins, and R. A. Lorenz, "Highlights Report for Fission Product Release Tests of Simulated LWR Fuel," ORNL/NRC/LTR85/1, February 1985.

12. Toshiyuki Yamashita, "Steam Oxidation of Zircaloy Cladding in the ORNL Fission Product Release Tests," NUREG/CR-4777 (ORNL/TM10272), March 1988.

13. S. K. Wisbey, "Preliminary Studies of the Morphology of Thermal Gradient Tube Deposits for Fission Product Release Experiments," NUREG/CR-4778 (ORNL/TM-10273), March 1988.

14. C. S. Webster and M. F. Osborne, "The Use of Fiber Optics for Remote Temperature Measurement in Fission Product Release Tests," NUREG/CR-4721 (ORNL/TM-10366), April 1989.

15. M. F. Osborne, J. L. Collins, R. A. Lorenz, J. R. Travis, C. S. Webster, and T. Yamashita, "Data Summary Report for Fission Product Release Test VI-1," NUREG/CR-5339 (ORNL/ TM-11104), June 1989. 
16. M. F. Osborne, J. L. Collins, R. A. Lorenz, J. R. Travis, and C. S. Webster, "Data Summary Report for Fission Product Release Test VI-2," NUREG/CR-5340 (ORNL/TM-11105), September 1989.

17. M. F. Osborne, J. L. Collins, R. A. Lorenz, J. R. Travis, C. S. Webster, H. K. Lee, T. Nakamura, and Y.-C. Tong, "Data Summary Report for Fission Product Release Test VI-3," NUREG/CR-5480 (ORNL/TM-11399), April 1990.
18. M. F. Osborne, R. A. Lorenz, J. L. Collins, J. R. Travis, C. S. Webster, and T. Nakamura, "Data Summary Report for Fission Product Release Test VI-4," NUREG/CR-5481 (ORNL/ TM-11400), October 1990.

19. M. F. Osborne, R. A. Lorenz, J. R. Travis, C. S. Webster, and J. L. Collins, "Data Summary Report for Fission Product Release Test VI-5," NUREG/CR-5666 (ORNL/TM-11743), October 1991. 


\section{Introduction}

This report summarizes data from the sixth test in a vertical test apparatus. This series of tests is designed to investigate fission product release from light-water reactor (LWR) fuel in steam and/or hydrogen in the temperature range of 2000 to $2700 \mathrm{~K}$. Six earlier tests, denoted HI-1 through HI-6, were conducted under similar conditions in a horizontal furnace at temperatures of 1675 to $2275 \mathrm{~K}\left(1400\right.$ to $\left.2000^{\circ} \mathrm{C}\right)$. The HI series tests were analyzed and reported previously, ${ }^{1}$ and comparable data summary reports are listed as items 1 through 6 in the Foreword. After revising the test apparatus to accommodate the vertical furnace, a new series of tests to higher temperatures, denoted VI-1 through VI-6, was initiated. ${ }^{2-6}$ All of this work has been summarized in Nuclear Safety.

The purpose of this work, which is sponsored by the U.S. Nuclear Regulatory Commission (NRC), is to obtain the experimental data needed to reliably assess the consequences of a variety of heatup accidents in LWRs. ${ }^{8}$ The specific objectives of this program are:

(1) to obtain fission product release and behavior data applicable to the analysis of reactor accidents, and
(2) to apply these data to the development of fission product release and transport models.

Tests of high-burnup LWR fuel are emphasized in this program. The applicability of simulated fuel (unirradiated $\mathrm{UO}_{2}$ containing radioactive fission product tracers) was considered, and several simulant tests have been conducted to provide valuable data about the behavior of specific fission product species.' All tests have been conducted at atmospheric pressure in helium mixed with either steam or hydrogen in a hot cell-mounted test apparatus.

The procedures and techniques used in preparing and conducting the test, as well as in posttest examination and analysis, were very similar to those used in earlier tests. The analytical techniques employed are listed in Table 1.1. This report provides a brief description of test VI-6 and a compilation of all results obtained to date. Other analyses, in particular neutron activation for iodine, are still in process and will be reported later. Thorough data evaluation and correlation of all results from the VI test series will be included in subsequent reviews and reports covering this series of fission product release tests at temperatures up to $2700 \mathrm{~K}$. 
Introduction

Table 1.1 Analytical techniques used for fission product analysis

\begin{tabular}{|c|c|c|c|}
\hline Technique & Time & Location & Elements \\
\hline \multirow[t]{3}{*}{ Gamma spectrometry } & Pretest, posttest & Fuel specimen & $\begin{array}{l}\text { Long-lived, gamma-emitting } \\
\text { fission products - Ru, Sb, Cs, } \\
\mathrm{Ce}, \mathrm{Eu}\end{array}$ \\
\hline & On-line & $\begin{array}{l}\text { Thermal gradient tube } \\
\text { (TGT), charcoal traps, } \\
\text { filters }\end{array}$ & Cs, $\mathbf{K r}$ \\
\hline & Posttest & $\begin{array}{l}\text { Furnace components, } \\
\text { TGT, filters }\end{array}$ & $\mathrm{Ru}, \mathrm{Sb}, \mathrm{Cs}, \mathrm{Ce}, \mathrm{Eu}$ \\
\hline $\begin{array}{l}\text { Neutron activation } \\
\text { analysis }\end{array}$ & Posttest & $\begin{array}{l}\text { Charcoal; solutions from } \\
\text { furnace, TGT, filters }\end{array}$ & $\mathrm{I}, \mathrm{Br}$ \\
\hline Chemical analysis & Posttest & Furnace, filters & $\mathrm{U}, \mathrm{Pu}$ \\
\hline $\begin{array}{l}\text { Inductively coupled } \\
\text { plasma-emission } \\
\text { spectrometry }\end{array}$ & Posttest & $\begin{array}{l}\text { Acid solutions from } \\
\text { furnace, TGT, or filters }\end{array}$ & $\begin{array}{l}\text { Many cations, especially Sr, } \\
\text { Mo, } \mathrm{Ru}, \mathrm{Te}, \mathrm{Ba}, \mathrm{U}\end{array}$ \\
\hline
\end{tabular}




\section{Description}

\section{Test Description}

The vertical test apparatus ${ }^{10}$ is operated remotely and is capable of conducting tests at temperatures up to $2700 \mathrm{~K}$ for time periods up to $60 \mathrm{~min}$ in reactive atmospheres, such as steam and/or hydrogen mixed with helium. Details of the furnace are shown in Figure 2.1, and the entire test apparatus installed in the hot cell is illustrated in Figure 2.2. Both manual and automatic optical pyrometers are used for temperature measurement, supplemented by thermocouples during the low-temperature heatup phase.

The released fission products are collected in three sequentially operated, parallel collection trains. Each train is composed of (1) a 7.6-mm-ID platinum or stainless steel-lined thermal gradient tube (TGT) designed for vapor condensation; (2) a filter package containing graduated fiberglass filters for aerosol collection and heated charcoal that had been impregnated with triethylenediamine (TEDA) for iodine sorption; and (3) cold charcoal traps for rare gas collection. The on-line releases of ${ }^{85} \mathrm{Kr}$ and ${ }^{137} \mathrm{Cs}$ are monitored by detectors observing these collector components. In steam atmosphere tests, a hot $\mathrm{CuO}$ bed is used to oxidize the hydrogen generated by reaction of steam with the Zircaloy cladding. The collection of this water in a condenser is measured continuously by a modified conductivity meter, thereby indicating the oxidation rate of the cladding. Details of the fission product collection system are shown in Figure 2.3. Included in the test VI-6 apparatus were two radiation detectors that were collimated to monitor the radioactivity (primarily ${ }^{134} \mathrm{Cs}$ and ${ }^{137} \mathrm{Cs}$ ) in the top and bottom regions of the fuel specimen. Data from these instruments should indicate any movement or collapse of the fuel during the test.

The tests planned for this vertical apparatus assumed that temperature (2000 to $2700 \mathrm{~K}$ ) was the dominant variable. The flow rate of reactive gas $(0.3$ to $1.5 \mathrm{~L} /$ $\mathrm{min}$ ) and time ( 1 to $60 \mathrm{~min}$ ) were considered to be important but secondary variables. The objectives of this particular test were to obtain release rate data from BR3 fuel heated at $2300 \mathrm{~K}$, first in hydrogen to allow cladding melting and runoff, then in steam to effect oxidation of the $\mathrm{UO}_{2}$ fuel pellets, for a total time of $60 \mathrm{~min}$. Test VI-2, which was heated at $2300 \mathrm{~K}$ in steam for $60 \mathrm{~min}$, provides a basis for comparing atmospheric effects.

\subsection{Fuel Specimen Data}

The test specimen was a $15.2-\mathrm{cm}$-long section of rod $\mathrm{I}-114$ from the BR3 reactor in Belgium, as shown in Figure 2.4. This fuel was irradiated from July 15, 1976, until September 26, 1980. Details of the irradiation and of the characteristics of this particular specimen were reported by Adams and Dabell and are listed in Table 2.1. The fuel in this rod had an initial enrichment of $5.76 \%{ }^{235} \mathrm{U}$, and the VI-6 specimen had attained a burnup of $\sim 42 \mathrm{MWd} / \mathrm{kg}$ during irradiation. Fission product inventories for the specimen were measured by direct gamma spectrometry of the fuel and were calculated with the ORIGEN2 computer program; ${ }^{11}$ these data are shown in Tables 2.2 and 2.3.

As reported by Adams and Dabell, no axial scan of the gamma radioactivity along the intact fuel rod was made before the rod was sectioned. Scans of nearby rods with similar operating histories, however, indicated that rod 1-114 had experienced no unusual temperature, power, or burnup histories during 1986. Reactor operating data showed that this fuel rod had operated at a maximum linear power of $222 \mathrm{~W} / \mathrm{cm}$ averaged over the $1-\mathrm{m}$ length, indicating that the fuel in the peak burnup region (near midlength) would have operated at a peak linear power of $\sim 285 \mathrm{~W} / \mathrm{cm}$ at that time. These data showed that the fuel had not experienced high enough operating temperatures to cause significant migration of the fission product cesium during irradiation. The data shown in Figure 2.5 were used to estimate fission gas release from the peak burnup region of a fuel rod. Using Figure 2.5 and the operating history, we estimate that $\sim 2 \%$ of the total krypton generated in the fuel had been released during irradiation. The conversion from average gas release to release from the peak power (and peak burnup) location was made using the previously described $D^{\prime}$ (empirical) method. ${ }^{12}$

\footnotetext{
'J. P. Adams and B. R. Dabell, Idaho National Engineering Laboratory, Idaho Falls, ID 83415, "Characteristics of $\mathrm{UO}_{2}-\mathrm{Zr}$ Fuel Rods Irradiated in the BR3 Reactor," private communication, 1986.
} 


\section{Description}

ORNL DWG BSA-612

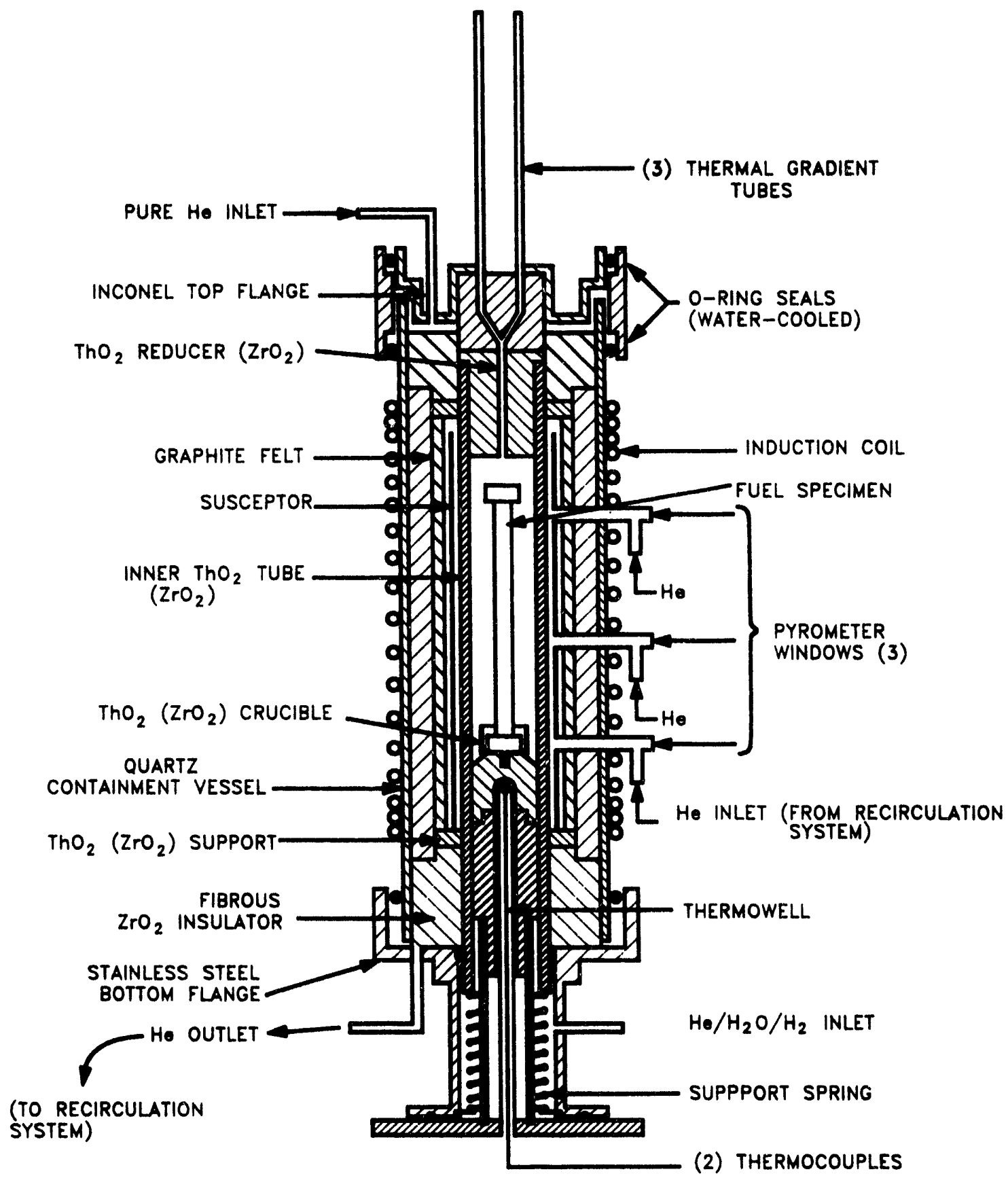

Figure 2.1 Vertical fission product release furnace, as used in test VI-6 


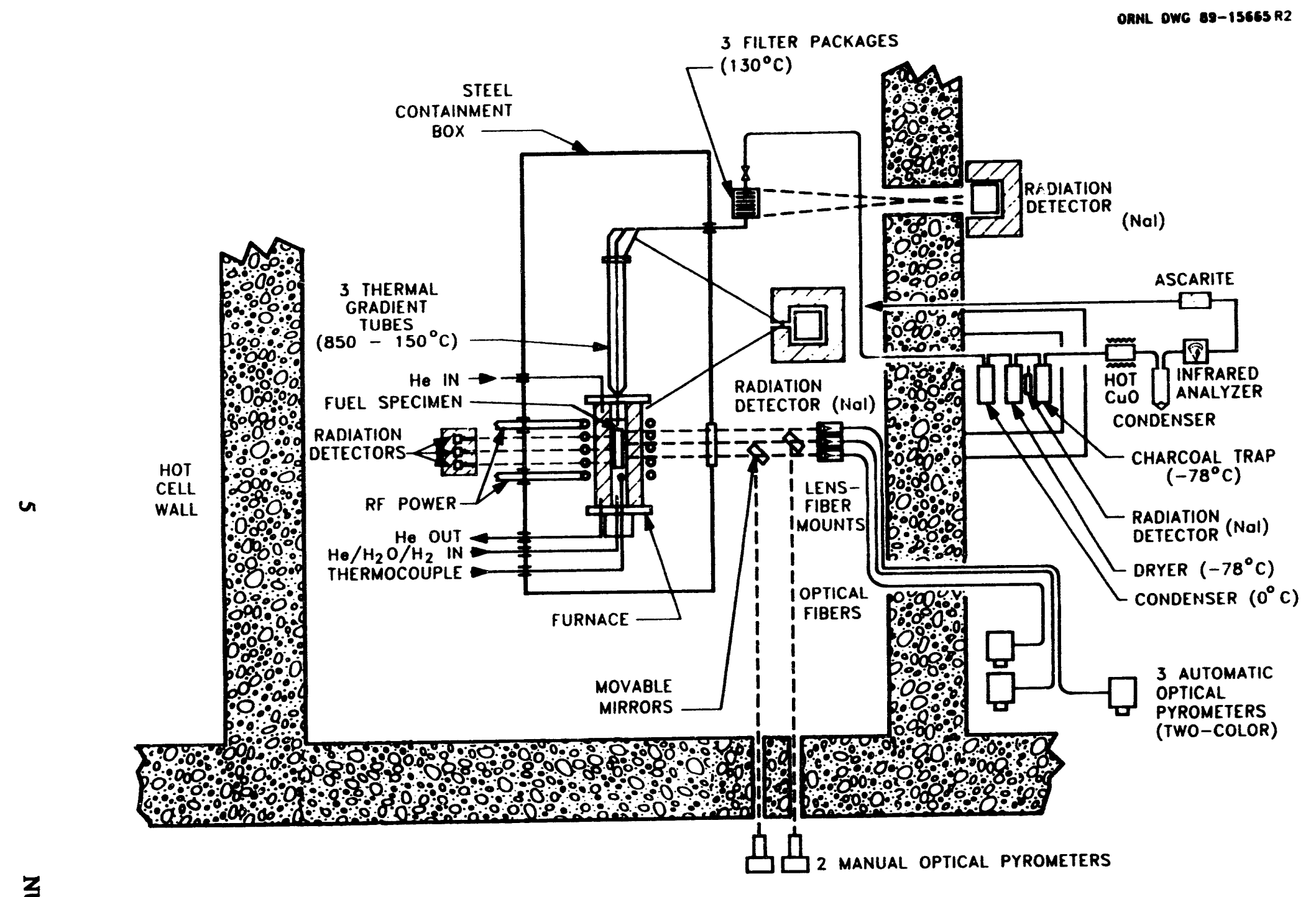

Figure 22 Vertical fission product release apparatus 


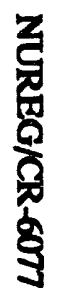

ORNL DWG 90-14768

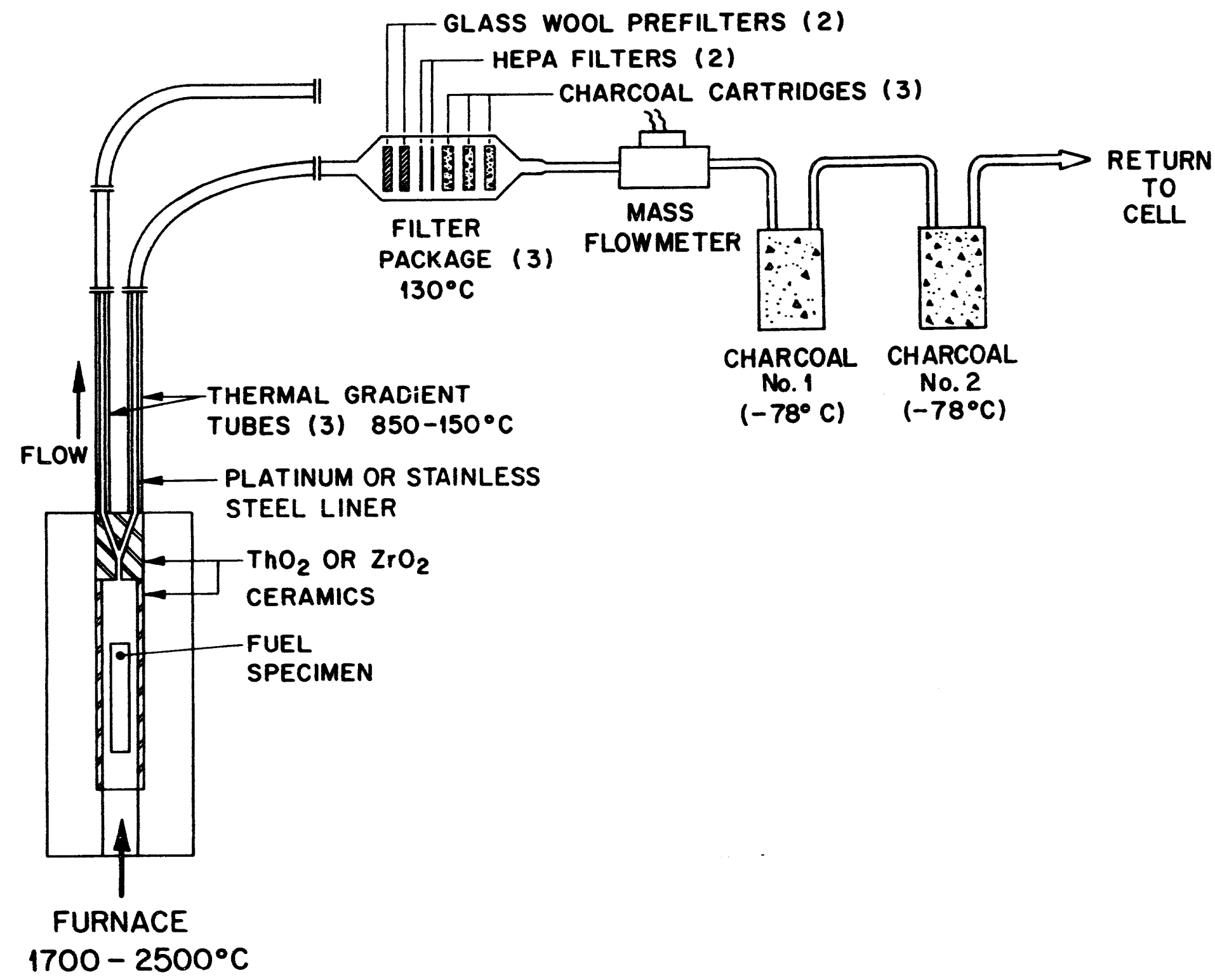

Figure 2.3 Components of the fission product collection system 
ORNL DWG 88-220

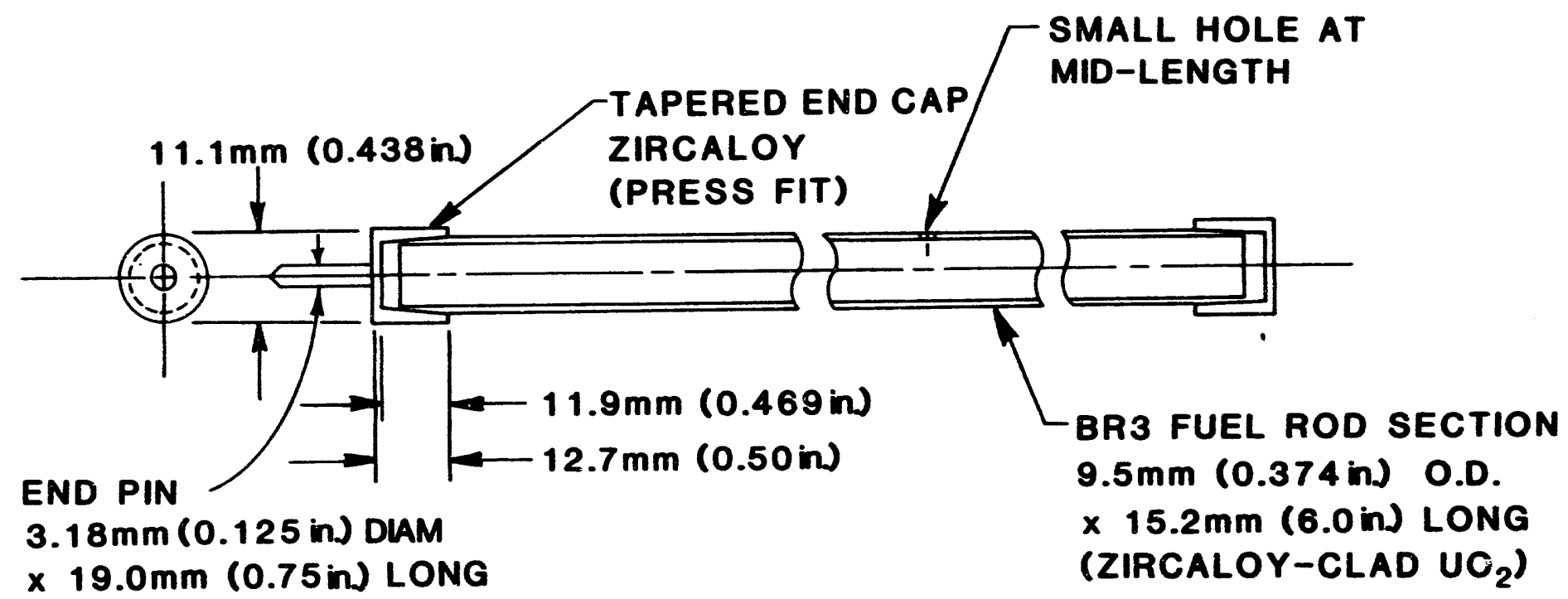

Figure 24 Details of the fuel specimen heated in test VI-6 


\section{Description}

Table 2.1 Data for fuel specimen used in test VI-6

Fuel specimen identification

Irradiation data

Period

Fuel specimen burnup

Maximum heat rating

Specimen data

Length

Fuel loading

Initial enrichment

Total weight

Weight of Zircaloy

Gas release during irradiation
Rod I-114, section 3

BR3 Reactor (Belgium)

July 15,1976 , to Sept. 26,1980

$42 \mathrm{MWd} / \mathrm{kg} \mathrm{U}$

$222 \mathrm{~W} / \mathrm{cm}$

$15.2 \mathrm{~cm}$

$81.5 \mathrm{~g} \mathrm{UO}_{2}(71.80 \mathrm{~g} \mathrm{U})$

$5.76 \%{ }^{235} \mathrm{U}$

$103.0 \mathrm{~g}$

$21.54 \mathrm{~g}$

$\sim 2 \%$ (from specimen) 
Table 2.2 Fission product and actinide inventories in test VI-6: nuclides

\begin{tabular}{lcc}
\hline & \multicolumn{2}{c}{ In VI-6 specimen* } \\
\cline { 2 - 3 } Nuclide & (mg) & (mC) \\
& At 7/191 & At 7/1/91 \\
\hline Fission products & & \\
Kr-85 & 1.207 & 473.9 \\
Sr-90 & 44.71 & 6,094 \\
Ru-106 & 0.0050 & 16.75 \\
Ag-110m & $7.9 \times 10^{-7}$ & 0.0038 \\
Sb-125 & 0.0597 & 61.61 \\
I-129 & 12.87 & 0.0023 \\
Cs-134 & 0.259 & 335.5 \\
Cs-137 & 88.74 & 7,726 \\
Ce-144 & 0.0016 & 5.068 \\
Eu-154 & 1.380 & 372.7 \\
Eu-155 & 0.249 & 115.7 \\
Total fission products & 3,118 & 29,400 \\
Actinides & & \\
U-234 & 21.58 & 0.135 \\
U-235 & 1,141 & 0.0025 \\
U-236 & 519.6 & 0.034 \\
U-238 & 66,090 & 0.0222 \\
Total U & 67,770 & 0.315 \\
Pu-238 & 13.41 & 229.5 \\
Pu-239 & 352.5 & 21.92 \\
Pu-240 & 161.6 & 36.83 \\
Pu-241 & 46.75 & 4,818 \\
Pu-242 & 24.79 & 0.095 \\
Total Pu & 599.0 & 5,106 \\
Total actinides & 68,460 & 5,286 \\
\hline
\end{tabular}

-VI-6 specimen contained 71.80 g U = 7.180E-5 MTU before irradiation. 
Table 2.3 Fission product and actinide inventories in test VI-6: elements

\begin{tabular}{lc}
\hline Element & $\begin{array}{c}\text { In VI-6 specimen* } \\
\text { (mg at 7/1/91) }\end{array}$ \\
\hline Se & 5.457 \\
Br & 2.097 \\
Kr & 36.87 \\
Rb & 36.30 \\
Sr & 84.08 \\
Y & 47.89 \\
Zr & 356.1 \\
Mo & 310.3 \\
Tc & 71.88 \\
Ru & 182.6 \\
Rh & 38.46 \\
Pd & 88.32 \\
Ag & 4.425 \\
Cd & 6.266 \\
In & 0.184 \\
Sn & 6.381 \\
Sb & 1.495 \\
Te & 40.03 \\
I & 15.92 \\
Xe & 474.7 \\
Cs & 232.6 \\
Ba & 152.7 \\
La & 114.1 \\
Ce & 223.4 \\
Eu & 10.91 \\
Total fission products & 3,118 \\
U & 67,770 \\
Pu & 599 \\
Total actinides & 68,460 \\
\hline
\end{tabular}

-Vl-6 specimen contained $71.80 \mathrm{~g} \mathrm{U}=7.180 \mathrm{E}-5 \mathrm{MTU}$ before irradiation. 


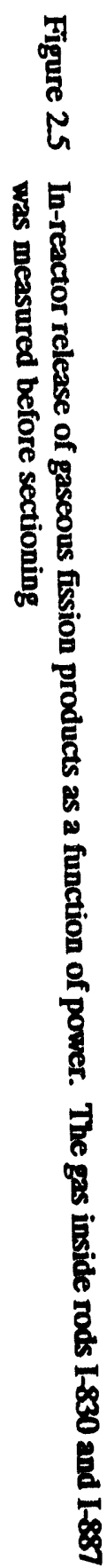

GAS RELEASE AT PEAK BURNUP REGION OF ROD (\%)

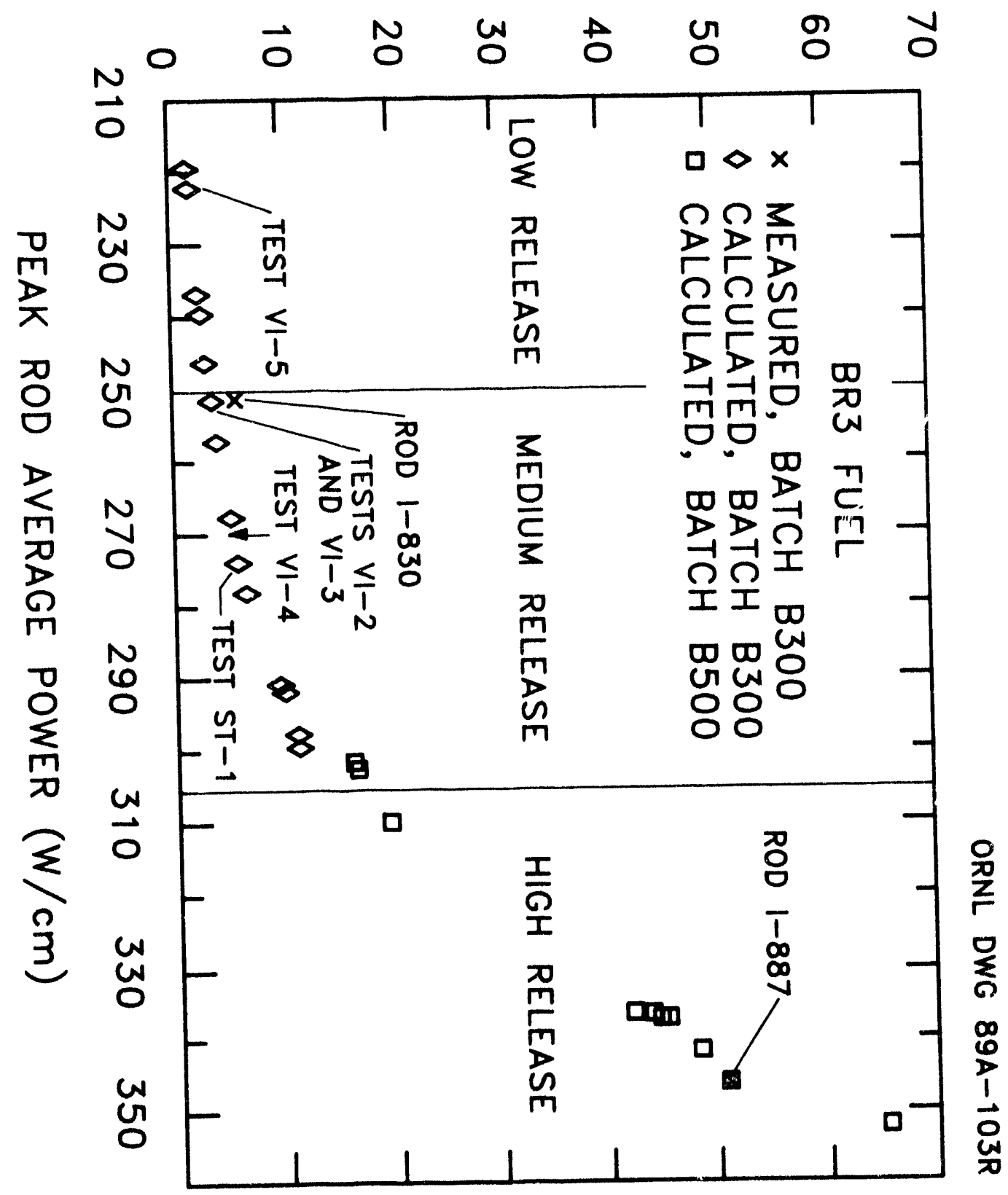




\section{Description}

In addition to the test VI-6 fuel specimen, three other $15.2-\mathrm{cm}$-long specimens were cut from rod I-114 and prepared for future testing. One of these specimens was heated in test VI-5. ${ }^{6}$ Three short samples (1 to $2 \mathrm{~cm}$ long) were cut for metallographic examination, for dissolution and chemical analysis, and as an archive sample for possible future use.

Tapered end caps of Zircaloy-2 were pressed onto the ends of the test specimen, not as gas seals, but to prevent loss of the fractured $\mathrm{UO}_{2}$ fuel during subsequent handling. The bottom end cap included a pin to facilitate vertical mounting. A small hole, $1.6 \mathrm{~mm}$ in diameter, was drilled through the cladding at midlength to serve as a standard leak for gas release during the heatup phase of the test. These details are shown in Figure 2.4.

The gamma-ray profile of the test VI-6 fuel specimen, as observed through a $0.25-\mathrm{mm}(0.010-\mathrm{in}$.) window, is shown in Figure 2.6. This profile, which is dominated by ${ }^{134} \mathrm{Cs}$ and ${ }^{137} \mathrm{Cs}$, indicates very uniform burnup of the fuel and fission product content along the specimen, as well as the location of individual fuel pellets. The axial distributions of ${ }^{134} \mathrm{Cs},{ }^{137} \mathrm{Cs},{ }^{154} \mathrm{Eu}$, and ${ }^{60} \mathrm{Co}$, as measured through a $1-\mathrm{cm}$ window at $1-\mathrm{cm}$ intervals, are shown in Figure 2.7. These data show that no significant migration of the volatile cesium occurred during irradiation.

\subsection{Test Conditions and Operation}

As in each of the previous experiments, the test apparatus was assembled by direct handling, which is possible because the hot cell and test apparatus are decontaminated after each test. Also, new $\mathrm{ZrO}_{2}$ furnace compon ints, new TGT liners of 0.002-in. (0.051-mm)-thick stainless steel, and new filter package components were prepared and installed. In most previous tests, platinum liners were used to provide a relatively unreactive surface for the deposition of fission products, so that effects on the chemical forms of the deposits would be minimized. In an effort to investigate the effects of a realistic reactor material on the forms of the deposits, stainless steel liners were used in test VI-6 and in some earlier tests. Only the transfer and loading of the highly radioactive fuel specimen and the final closure of the furnace and containment box were done remotely. No in-cell operations were required during the test. Before heating was begun, the test apparatus was evacuated and purged with helium.

This test was intended to study the effect of steam oxidation of the $\mathrm{UO}_{2}$ on fission product release at $2300 \mathrm{~K}$. In earlier tests in steam, VI-1, VI-2, and VI-3, the oxidized cladding had remained largely intact, serving as a barrier to effective $\mathrm{UO}_{2}$-steam contact. The operating conditions are summarized in Table 2.4, and the temperature history similar to that in test VI-2 is shown in Figure 2.8. The heatup rate in test VI-6 was $\sim 0.8 \mathrm{~K} / \mathrm{s}$, which is similar to those in tests VI-1 and VI-2. Tests using $\mathrm{ThO}_{2}$ ceramic furnace tubes (VI-3 and VI-5) required slower heatup rates to avoid fracturing by thermal shock.

The more important events during the test are listed in the test chronology, Table 2.5. The time periods for operation of the three collection trains (see Figure 2.8) were for Train A, 0 to $55 \mathrm{~min}$; for Train B, 55 to $73 \mathrm{~min}$; and for Train C, $73 \mathrm{~min}$ to the end of the test, $\sim 200 \mathrm{~min}$, including cooldown. A preheat period was included to slowly heat the specimen to $\sim 550 \mathrm{~K}$ in helium prior to beginning hydrogen flow to the furnace. Time zero was defined as that time when the controlled heating ramp was begun, with stable gas (hydrogen + helium) flow through the warm furnace established. Temperature measurement and control were generally good. The 12 -min period at $\sim 1400 \mathrm{~K}$ was included to ensure heatup of ceramics in the outlet end of the furnace and to compare the data from the optical pyrometers before any significant release of fission products had occurred.

With one exception, operation of test VI-6 was conducted as planned. At the transition from Test Phase A (hydrogen + helium atmosphere) to Test Phase B (steam + helium atmosphere), the valves for switching the flows of reactive gases were operated correctly, but a partially open bypass valve allowed most of the steam to escape from the system, rather than to flow through the furnace as planued. This loss of steam was detected and corrected at a test time of $93 \mathrm{~min}$, 20 min into Test Phase $C$. 


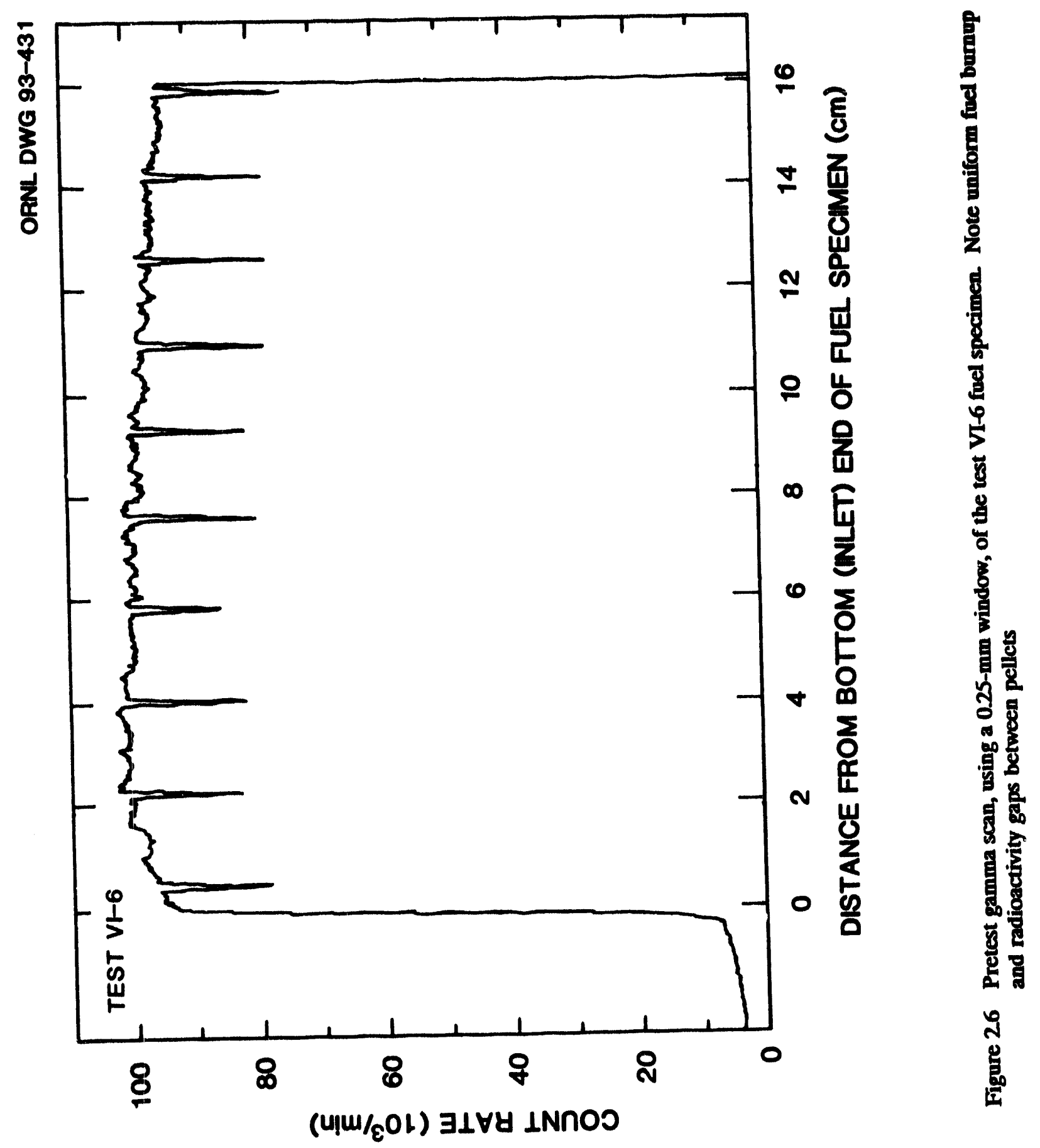




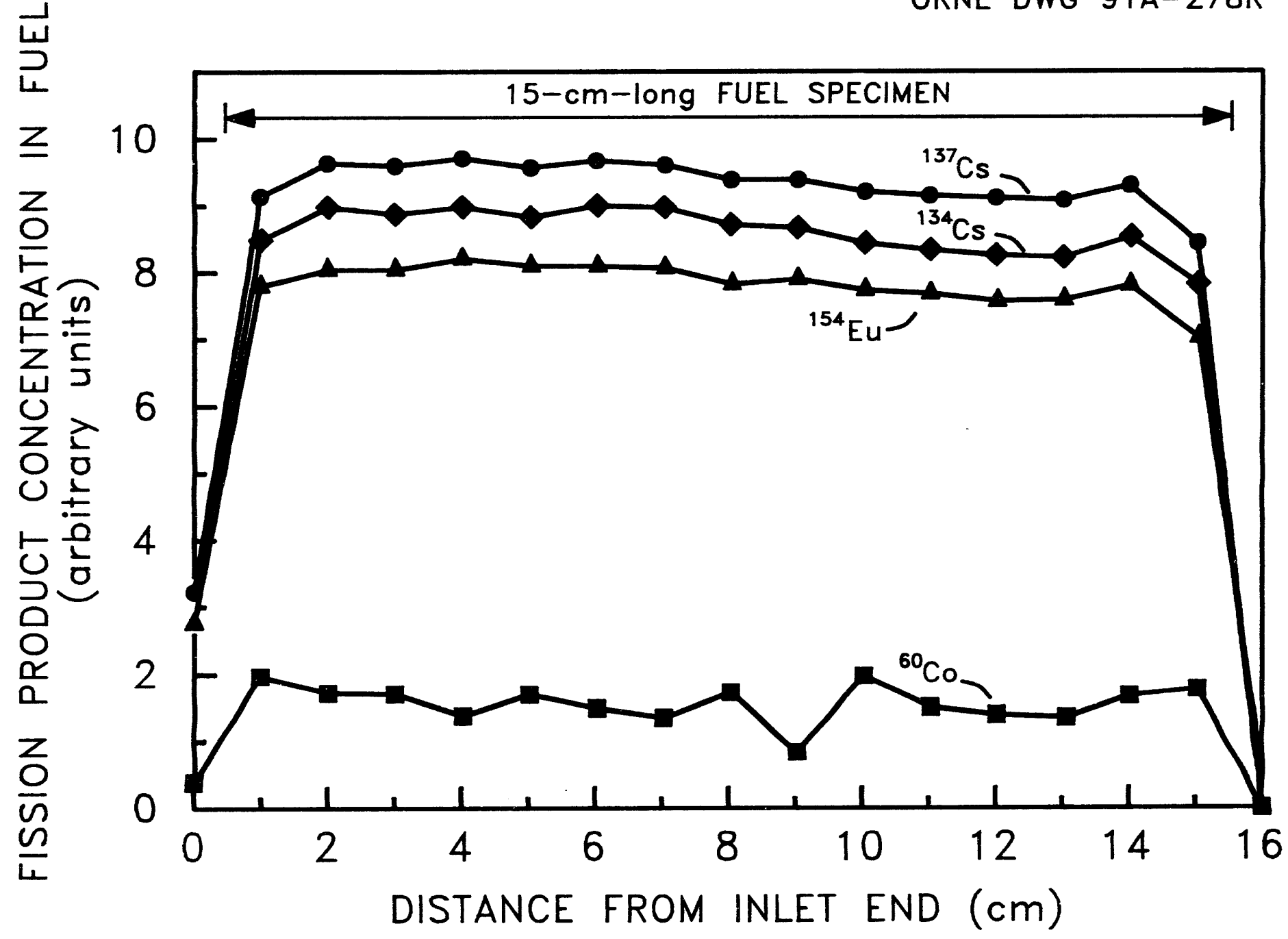

Figure 27 Distribution of ${ }^{134} \mathrm{Cs},{ }^{137} \mathrm{Cs}$, and ${ }^{154} \mathrm{Eu}$ in the fuel and for ${ }^{60} \mathrm{Co}$ in the cladding of the test $\mathrm{VI}-6$ fuel specimen 
Table 24 Operating data for test VI-6

\begin{tabular}{ll}
\hline Specimen temperature (K) & -570 \\
At start of heatup ramp & 1415 \\
During 10-min period to check pyrometers & 2310 \\
During 60-min period (Phases A, B, and C) & $0.83 \mathrm{~K} / \mathrm{s}$ \\
Heatup rate of Phase A & $0.60 \mathrm{~K} / \mathrm{s}$ \\
Cooldown rate & $72 \mathrm{~min}$ \\
Time above $2000 \mathrm{~K}$ & \\
Nominal gas flow rate data (L/min at $20^{\circ} \mathrm{C}, 1$ bar)*** & \\
During Phase A & 0.20 \\
$50 \% \mathrm{H}_{2}+\mathrm{He}$ recirculation system & 0.80 \\
$50 \% \mathrm{H}_{2}+$ He to fuel specimen & \\
During Phases B and C & 0.20 \\
He to recirculation system & 0.30 \\
He to fuel specimen & $1.0^{+}$ \\
Steam to fuel specimen & 1.5 \\
Recirculation/purification system & \\
\hline
\end{tabular}

- Measured by mass flowmeters.

- Absolute pressure in furnace during test was $0.09906 \mathrm{MPa}(742 \mathrm{~mm} \mathrm{Hg})$.

+During Phase B and first 17 min of Phase C, steam flow across fuel specimen was reduced by an unknown amount because of leakage. 


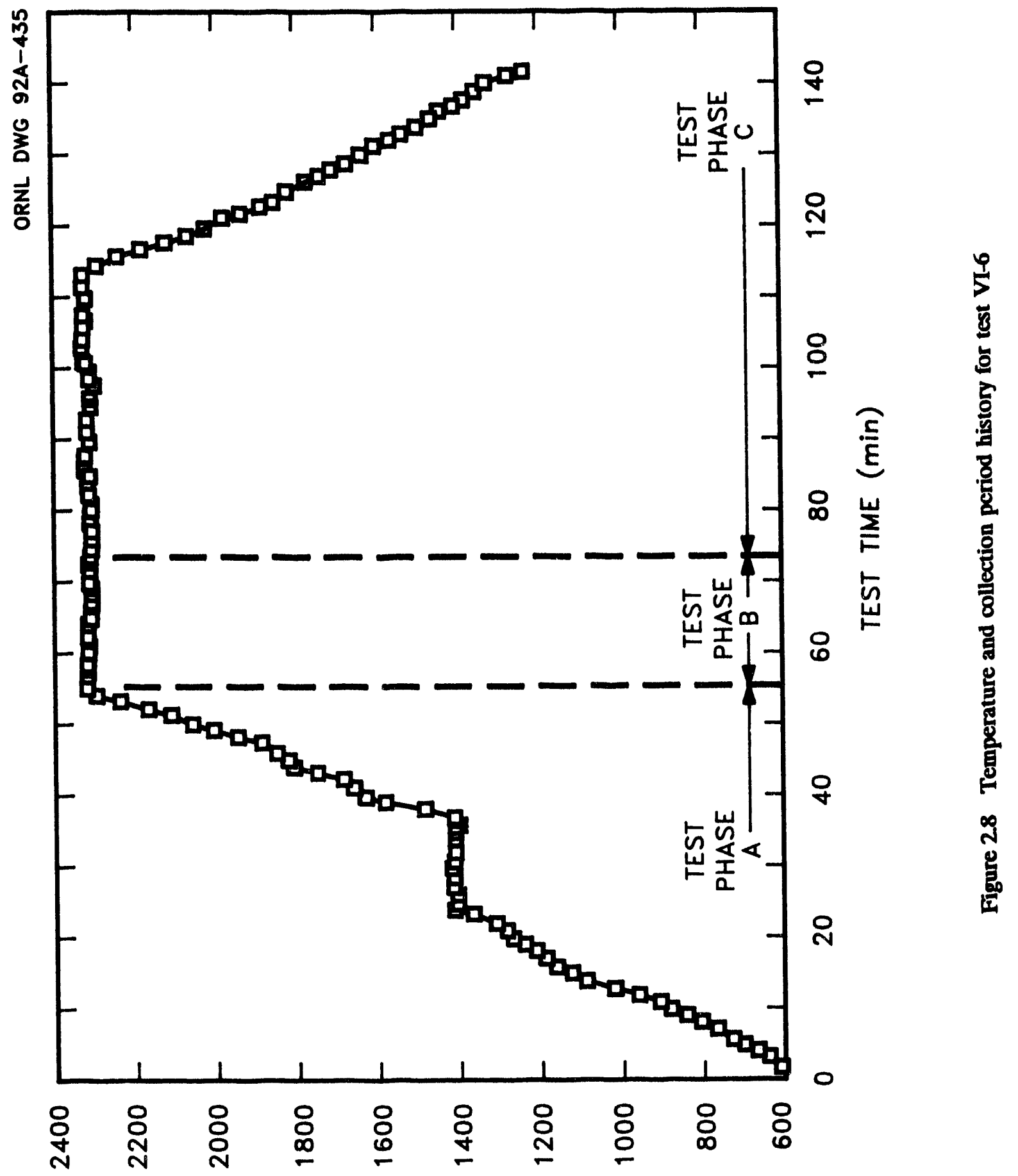

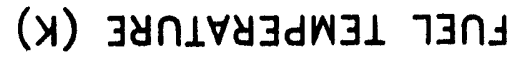


Table 2.5 Chronology of test VI-6, July 11, 1991

\begin{tabular}{|c|c|c|c|}
\hline \multirow[b]{2}{*}{ Event/observation } & \multicolumn{2}{|c|}{ Time } & \multirow{2}{*}{$\begin{array}{c}\begin{array}{c}\text { Furnace temperature } \\
\text { corrected (K) }\end{array} \\
\text { Center }\end{array}$} \\
\hline & $\begin{array}{c}\text { Clock } \\
\text { (h) }\end{array}$ & $\begin{array}{c}\text { Test } \\
\text { (min) }\end{array}$ & \\
\hline $\begin{array}{l}\text { Load fuel into furnace } \\
\text { Complete leak checks } \\
\text { Begin system preheat, TGTs and filters } \\
\text { Begin furnace preheat with gas flow to furnace } \\
\text { Stable flow and temperature }\end{array}$ & $\begin{array}{l}2015^{*} \\
2100^{*} \\
1000 \\
1155 \\
1330\end{array}$ & & $\begin{array}{l}\text { RT** } \\
\text { RT } \\
\text { RT } \\
\text { RT } \\
620^{+}\end{array}$ \\
\hline $\begin{array}{l}\text { Test Phase A } \\
\text { Start ramp to } \sim 1400 \mathrm{~K} \\
\text { First Micro No. } 1 \mathrm{~T} \text { measurement } \\
\text { Reached } \sim 1400 \mathrm{~K} \text { plateau } \\
\text { Resume ramp to } 2300 \mathrm{~K} \text {, observed } \mathrm{Kr} \\
\text { release } \\
\text { First Cs detected, on TGT } \\
\text { Rapid } \mathrm{Kr} \text { release, Cs on filter } \\
\text { Reached } 2300 \mathrm{~K} \text { plateau, hold } 2 \text { min } \\
\text { End Phase } \mathrm{A} \text {, stop } \mathrm{H}_{2} \text { flow, begin steam flow }\end{array}$ & $\begin{array}{l}1445 \\
1458 \\
1508 \\
\\
1520 \\
1525 \\
1527 \\
1538 \\
1540\end{array}$ & $\begin{array}{r}0 \\
13 \\
23 \\
\\
35 \\
40 \\
42 \\
53 \\
55\end{array}$ & $\begin{array}{c}606^{+} \\
1088 \\
1420 \\
1406 \\
1668 \\
1750 \\
2294 \\
2318\end{array}$ \\
\hline $\begin{array}{l}\text { Test Phase B } \\
\text { Begin Phase B, hold } 18 \text { min } \\
\text { End Phase B }\end{array}$ & $\begin{array}{l}1540 \\
1558\end{array}$ & $\begin{array}{l}55 \\
73\end{array}$ & $\begin{array}{l}2318 \\
2306\end{array}$ \\
\hline $\begin{array}{l}\text { Test Phase C } \\
\text { Begin Phase C, hold } 40 \text { min } \\
\text { Closed steam leak } \\
\text { End } 2300 \mathrm{~K} \text { plateau, reduce power to cool } \\
\text { Cooling rate } \sim 50 / \mathrm{min} \\
\text { Turn power off } \\
\text { Cooling rate } \sim 35 / \mathrm{min} \\
\text { Cooling rate } \sim 30 / \mathrm{min} \\
\text { Last pyrometer measurements } \\
\text { Test essentially complete } \\
\text { End Phase } C \text {, stopped gas flow }\end{array}$ & $\begin{array}{l}1558 \\
1616 \\
1638 \\
1644 \\
1646 \\
1650 \\
1700 \\
1708 \\
1718 \\
1807\end{array}$ & $\begin{array}{r}73 \\
91 \\
113 \\
119 \\
121 \\
125 \\
135 \\
143 \\
153 \\
202\end{array}$ & $\begin{array}{r}2306 \\
2314 \\
2323 \\
2023 \\
1933 \\
1766 \\
1437 \\
1226 \\
\sim 1000^{+} \\
\sim 450^{+}\end{array}$ \\
\hline
\end{tabular}

-July 10, 1991.

"RT = room temperature.

+Based on thermocouple measurement. 


\subsection{Posttest Disassembly and Examination}

After the test was completed, the apparatus was monitored for the distribution of radioactivity before disassembly was begun. The highest concentrations of radioactivity were found at the furnace exit and in the first (lower) half of the TGTs. Initially, the filter assemblies and the top furnace flange-TGT assembly, containing the TGT liners, were removed, sealed, and transferred to another hot cell to avoid potential contamination from fuel handling. The $\mathrm{ZrO}_{2}$ top end plug was removed from the furnace tube to allow observation of the interior. The photo in Figure 2.9 shows a top view of the open furnace with the $\mathrm{UO}_{2}$ fuel column tilted to one side but still standing. After photography, the furnace cavity was filled with epoxy resin to preserve the geometry of the degraded fuel specimen during handling and any sectioning and microstructural examination. After removal of the fuel-furnace tube assembly from the furnace, it was analyzed in detail by gamma spectrometry. 

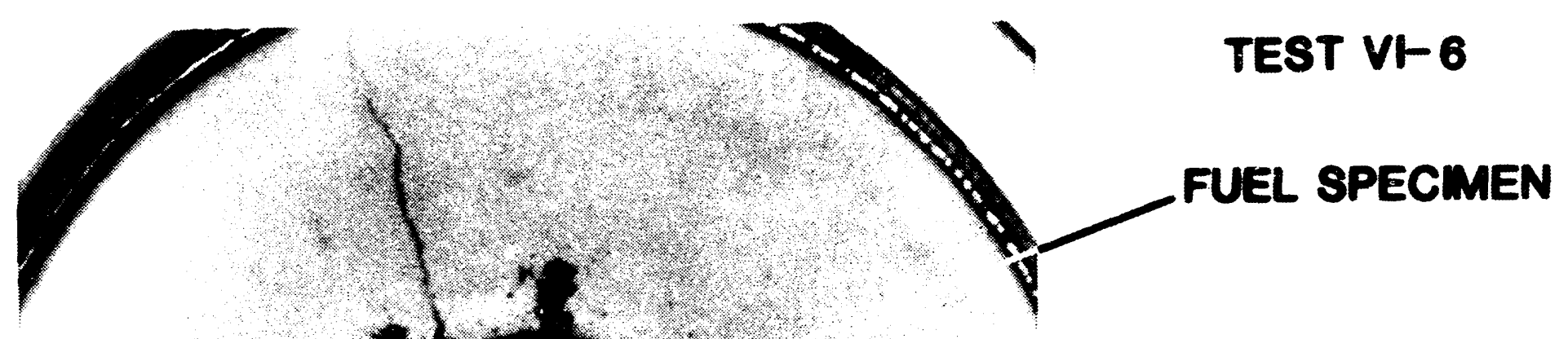

.
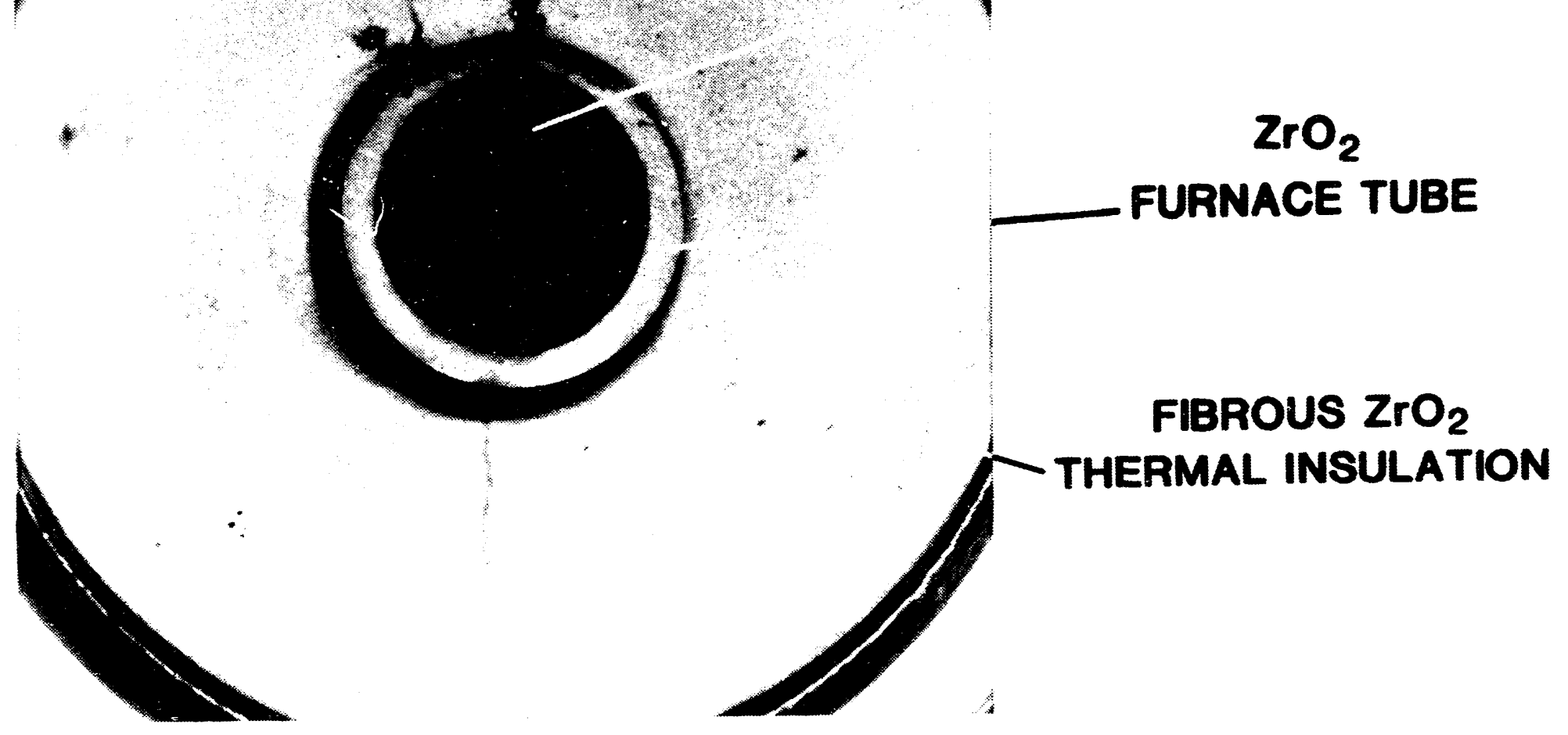

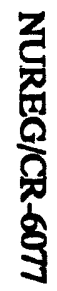




\section{Test Results}

\subsection{Gamma Spectrometry Data}

After the test, all experimental components and collectors were analyzed under well-defined geometry to determine the concentration of the gamma-emitting fission products. The previously proven empirical method of determining the effective shielding to obtain a mass balance for cesium among several of the ${ }^{134} \mathrm{Cs}$ gamma-ray energies was used. ${ }^{2}$

Pretest gamma spectrometric analysis of the $15.2-\mathrm{cm}$ long fuel specimen was used to determine the fission product inventories in the fuel. Long-lived gamma emitters - ${ }^{106} \mathrm{Ru},{ }^{125} \mathrm{Sb},{ }^{134} \mathrm{Cs}$, ${ }^{137} \mathrm{Cs}$, ${ }^{154} \mathrm{Eu}$, and ${ }^{60} \mathrm{Co}-$ were determined directly. A calculation by the computer program ORIGEN2 supplied the inventory values for other fission products, activation products, and fuel nuclides, as shown in Tables 2.2 and 2.3. Based on measurements at $1-\mathrm{cm}$ intervals of the ${ }^{134} \mathrm{Cs},{ }^{137} \mathrm{Cs}$, and ${ }^{154} \mathrm{Eu}$, as shown in Figure 2.7, the axial distributions of the major fission products were relatively uniform along the rod. The uniform axial distribution of the ${ }^{\infty} \mathrm{Co}$ in the Zircaloy cladding, also shown in Figure 2.7, is further verification of a uniform neutron dose (which indicates a similar burnup distribution) during irradiation.

The posttest distributions of ${ }^{106} \mathrm{Ru},{ }^{137} \mathrm{Cs}$, and ${ }^{154} \mathrm{Eu}$, as determined by gamma analysis of $1-\mathrm{cm}$-long sections of the fuel-furnace tube assembly, are shown in Figure 3.1, and the corresponding data for ${ }^{106} \mathrm{Ru},{ }^{125} \mathrm{Sb}$, and ${ }^{\infty} \mathrm{Co}$ are shown in Figure 3.2. In the region where the fuel was originally located $(0$ to $15.2 \mathrm{~cm}$ in both figures), the dominant species were ${ }^{106} \mathrm{Ru}$ and ${ }^{154} \mathrm{Eu}$. However, relocation of all gamma emitters is apparent. Firstly, most of the ${ }^{137} \mathrm{Cs}$ had been released from the hot zone of the furnace, with the remainder distributed over the original fuel zone (presumably in the $\mathrm{UO}_{2}$ fuel) at $\sim 20 \%$ of the original level. The ${ }^{106} \mathrm{Ru}$ and the ${ }^{154} \mathrm{Eu}$ distributions were similar, with greater than original concentrations near the bottom end of the original fuel location and lower concentrations, 50 to $90 \%$ of original, over the upper $60 \%$ of the original fuel location. These data indicate that some limited fuel collapse or meltdown had occurred, but that most of the fuel remained in a vertical column, as had been concluded from the in-cell radiation detector measurements during the tests. The distributions of ${ }^{60} \mathrm{Co}$ and ${ }^{125} \mathrm{Sb}$ (see Figure 3.2) had been drastically altered. Very high concentrations of these two nuclides appeared 3 to $4 \mathrm{~cm}$ below the original fuel location, clearly identifying a large deposit of the Zircaloy cladding that contained the ${ }^{\infty} \mathrm{Co}$, an activation product, and a significant concentration of ${ }^{106} \mathrm{Ru}$ as well.

In general, we believe that ${ }^{144} \mathrm{Ce}$ is the best indicator of fuel location. Because of the long decay time for the fuel in test VI-6 ( $\sim 12 y)$, however, the counting precision for ${ }^{14} \mathrm{Ce}\left(\mathrm{T}_{1 / 2}=284 \mathrm{~d}\right)$ was poor. Therefore, in test VI-6, ${ }^{154} \mathrm{Eu}$ is believed to be the best indicator for the location of $\mathrm{UO}_{2}$ fuel. Since some ${ }^{154} \mathrm{Eu}$ was found below the original fuel location, it appears that a small amount of $\mathrm{UO}_{2}$ either fell down as particles of fuel or was dissolved and carried down by the molten Zircaloy cladding.

As has been typical of these tests of high-burnup, long-decayed fuel, ${ }^{137} \mathrm{Cs}$ and ${ }^{134} \mathrm{Cs}$ were the dominant activities in almost all samples of released material and interfered with the analysis of less abundant fission products. The integral release behavior of krypton, as functions of time and temperature, is illustrated in Figure 3.3. The cesium release behaviors from the top and bottom regions of the fuel specimen, as indicated by the in-cell fuel monitors, are compared with this krypton release curve in Figure 3.4. This figure indicates that cesium release from the top of the specimen occurred somewhat earlier than from the bottom, suggesting a higher temperature at the top. The distributions of the cesium release to the TGTs (primarily vapor forms) and to the filters (primarily aerosol forms) are shown in Figure 3.5. These data were obtained from the NaI(Tl) detectors which measured ${ }^{137} \mathrm{Cs}$ directly. The latter are believed to be more reliable than the fuel monitors that supplied the gross gamma data shown in Figure 3.4. These curves in Figures 3.3, 3.4, and 3.5 show that the maximum release rate occurred during the period of clad melting and rundown, at temperatures of 2050 to $2300 \mathrm{~K}$ (at 50 to $54 \mathrm{~min}$ ), as was observed in test VI-5 in hydrogen. ${ }^{6}$ During Test Phase B and the first $20 \mathrm{~min}$ of Test Phase $C$, the period of very low flow rate because of the steam leak, $\mathrm{Kr}$ and $\mathrm{Cs}$ release rates declined. When high steam flow was established 


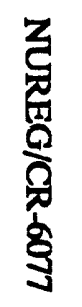

ORNL DWG 92-718

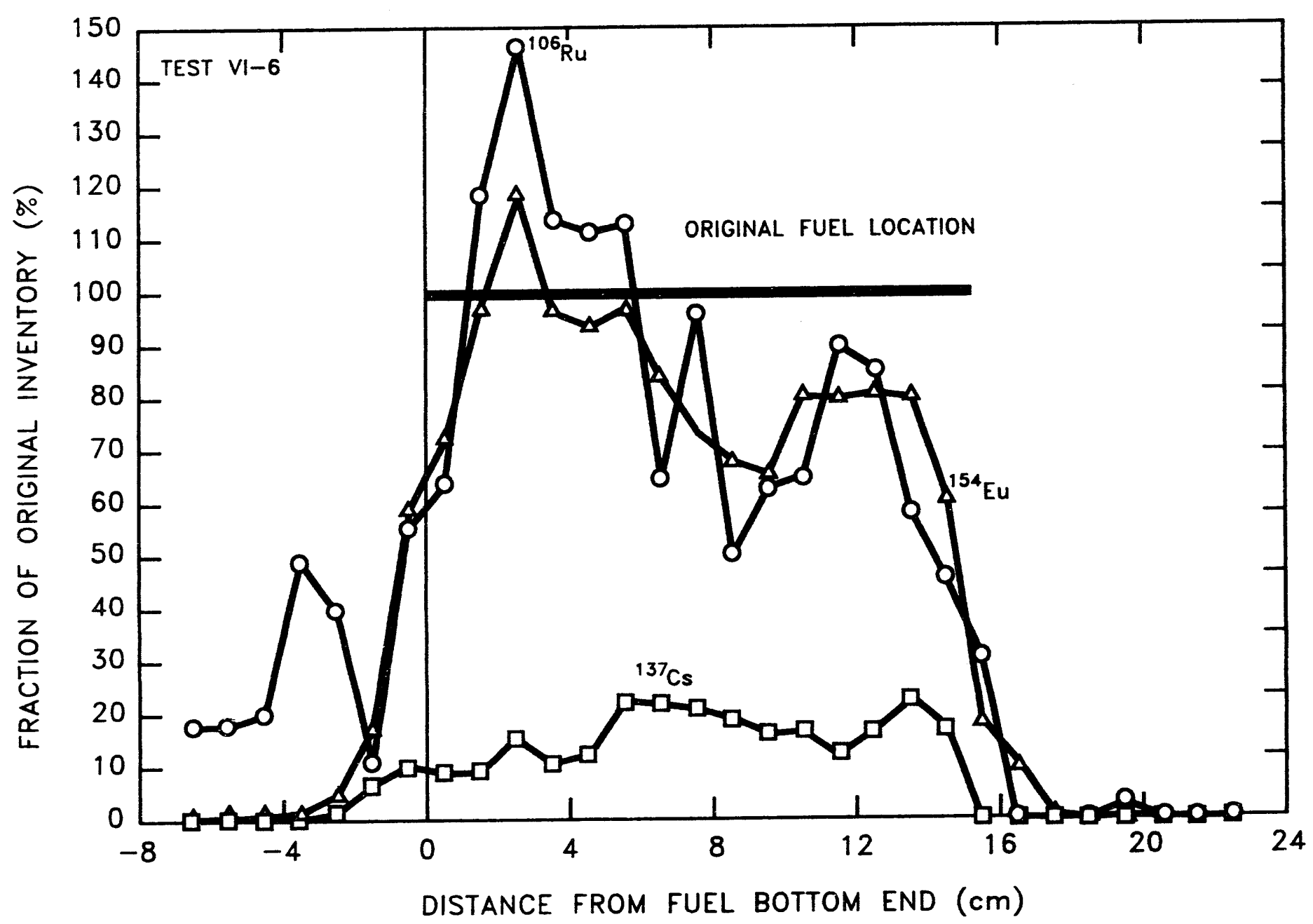

Figure 3.1 Distributions of fission product ${ }^{10} \mathrm{Ru},{ }^{137} \mathrm{C}$, and ${ }^{154} \mathrm{Eu}$ in the fuel-furnace tube assembly after test VI-6 
ORNL DWG 92-717

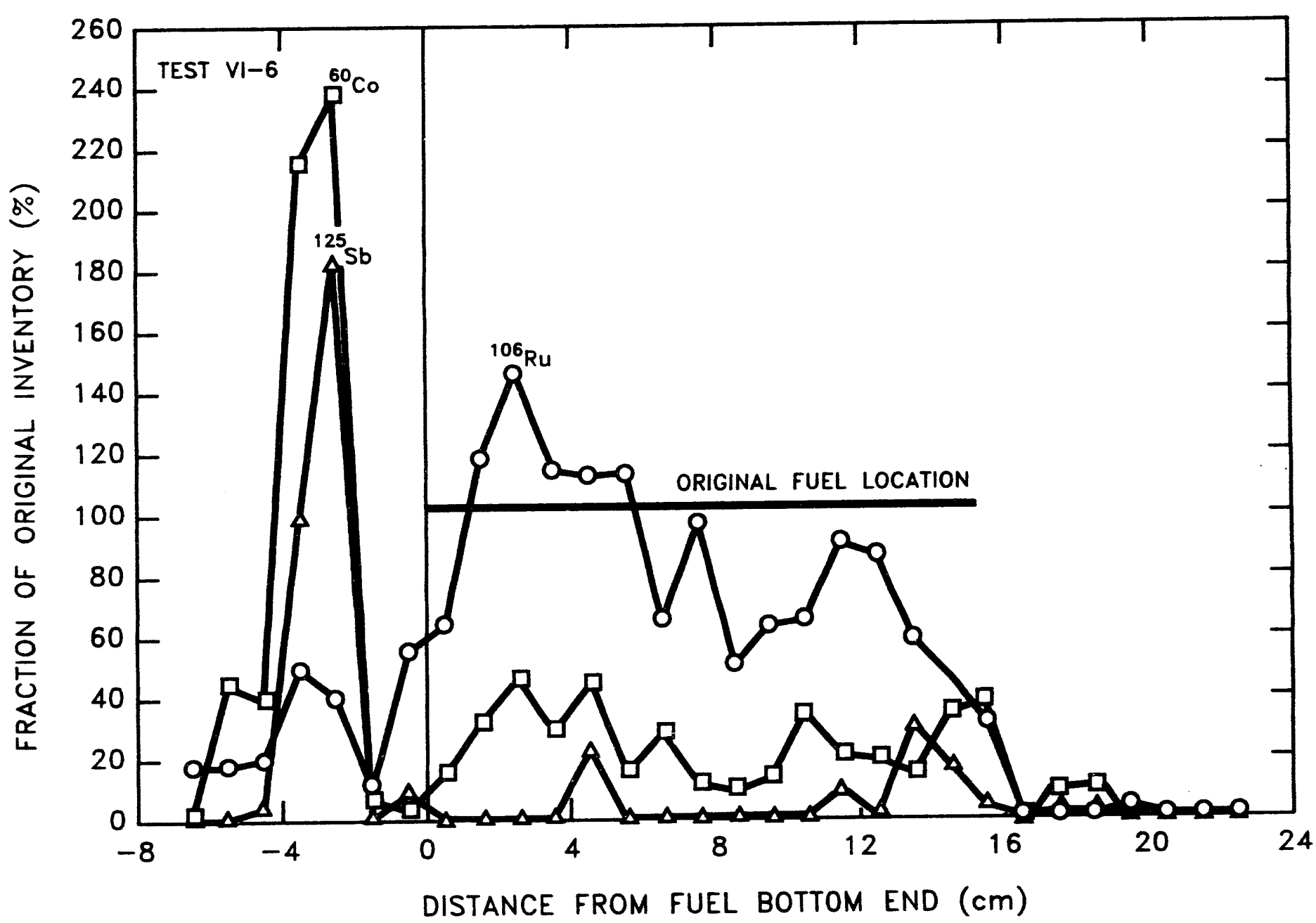

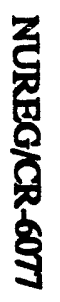

Figure 3.2 Distribution of ${ }^{10} \mathrm{Ru},{ }^{105} \mathrm{Sb}$, and ${ }^{\infty} \mathrm{Co}$ in the fuel-furnace tube assembly after test VI-6 


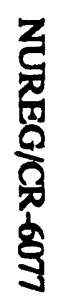

ORNL DWG 92A-720

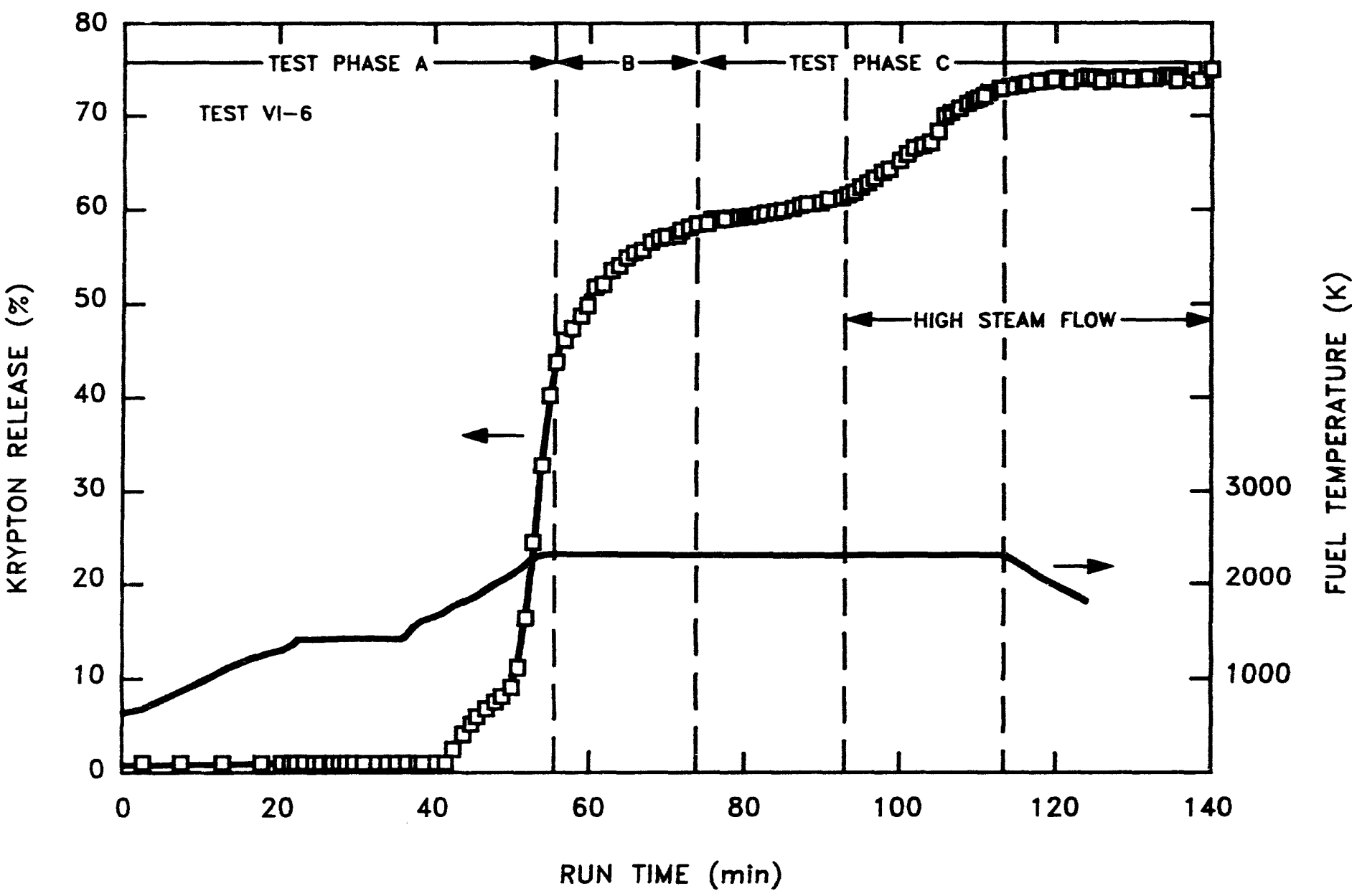

Figure 3.3 Release behavior of ${ }^{85} \mathrm{Kr}$ vs time and temperature in test VI-6 


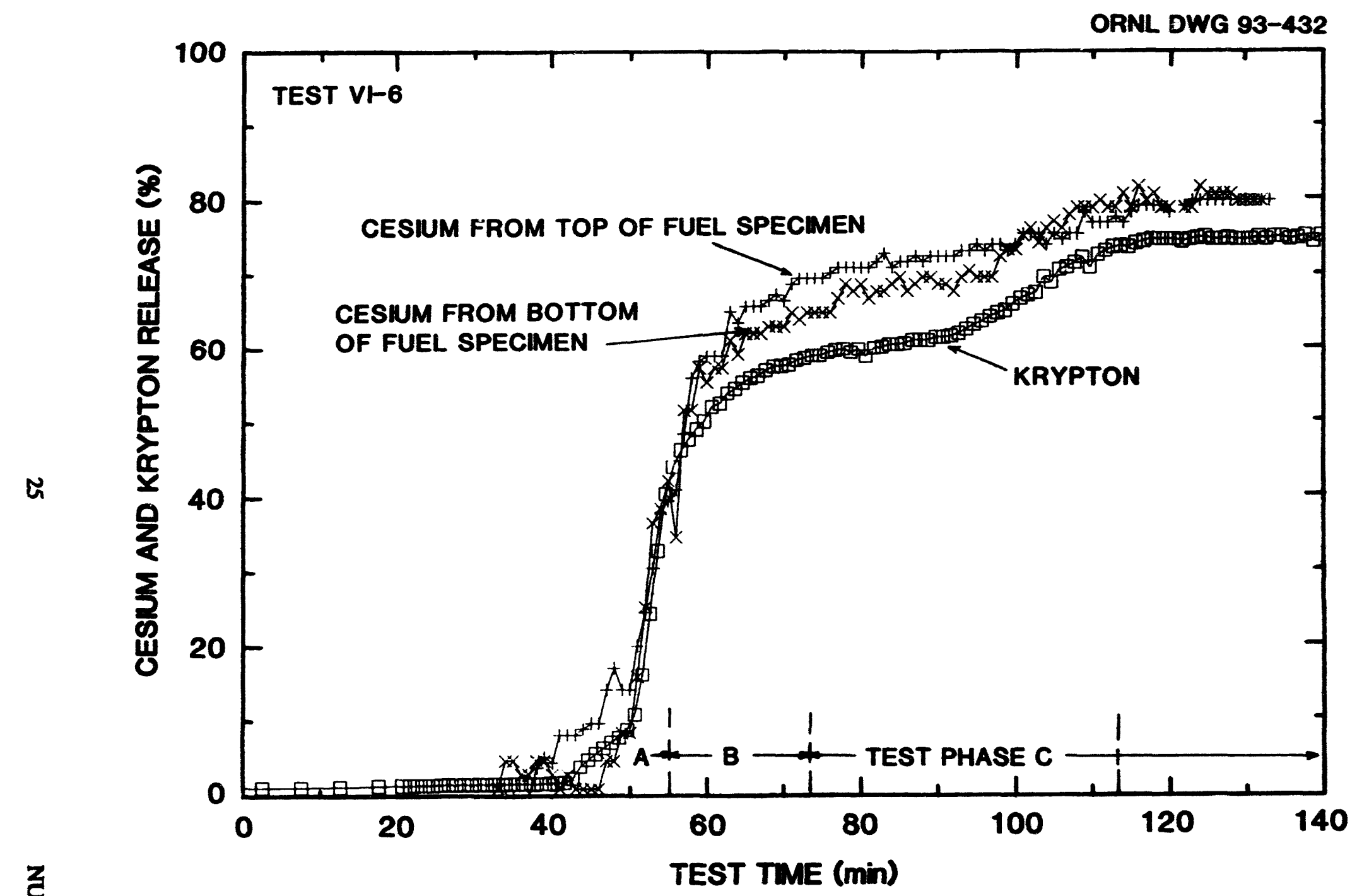

Figure 3.4 Release behavior of ${ }^{\text {wn }} \mathrm{CS}$ from fuel during tcst VI-6, as indicated by detectors monitoring top and bottom regions of the fuel specimen 


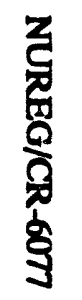

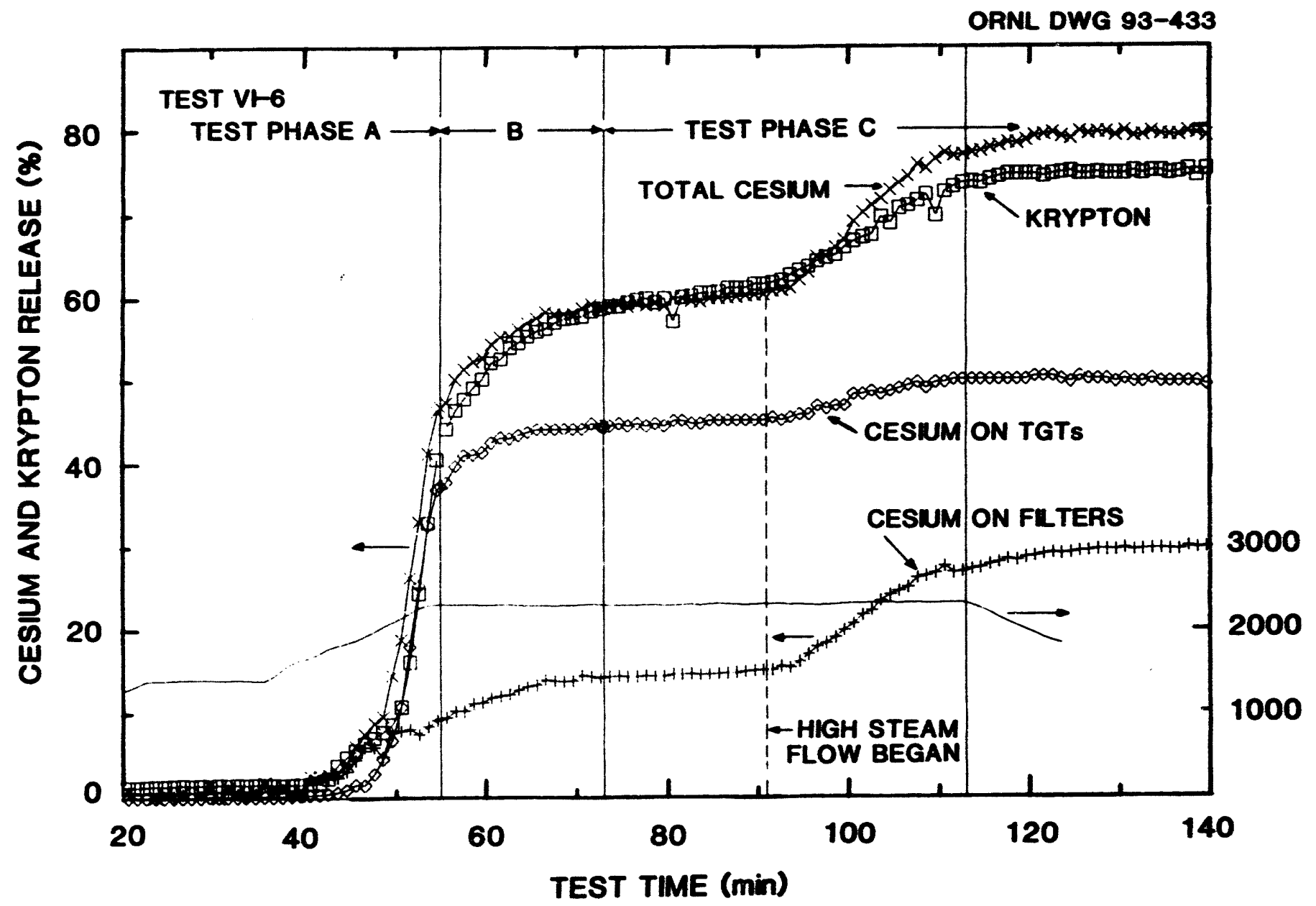

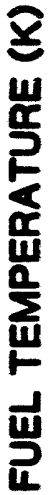

Figure 3.5 On-line distribution of released cesium forms, vapor to TGTs and aerosol fiters, compared to lryplom release behavior 
across the fuel specimen, at a test time of $\mathbf{9 3} \mathbf{m i n}$, a rapid increase in release rates was observed, showing the effect of steam oxidation on the $\mathrm{UO}_{2}$.

A summary of the fractional release results for $\mathrm{Kr}, \mathrm{Sb}$, $\mathrm{Cs}$, and Eu, as determined by gamma spectrometry, and for ${ }^{129} \mathrm{I}$, as determined by neutron activation analysis, is presented in Table 3.1. Although no data for ${ }^{134} \mathrm{Cs}$ are shown, the agreement with ${ }^{137} \mathrm{Cs}$ was consistently good (within $\pm 3 \%$ ) at all locations. Since there is no apparent reason for a separation of the two Cs radionuclides, this is a good indication of the precision of the analyses. The distribution of cesium within the test apparatus is shown in detail in Table 3.2. An unusually large fraction, $-54.3 \%$, of the cesium released from the fuel was retained in the furnace in test VI-6. The fractional retention values for cesium wit.an the furnaces for the six VI series tests are compared in Table 3.3. Except for test VI-4 ( $2440 \mathrm{~K}$ in hydrogen), which had a furnace retention fraction of $47.1 \%$, only 4 to $11 \%$ of the released cesium was retained in any previous VI test. As observed in other tests, this suggests that cesium reacted with the $\mathrm{ZrO}_{2}$ ceramics to form some cesium compound, probably $\mathrm{Cs}_{2} \mathrm{ZrO}_{3}$, more efficiently under these conditions than in steam, or at different temperatures. ${ }^{13}$

The measured distributions for the released ${ }^{125} \mathrm{Sb}$ and ${ }^{154} \mathrm{Eu}$ within the test apparatus are shown in Table 3.4. Although these nuclides are of relatively low yield and are not among the most hazardous, they have intermediate half-lives and strong gamma rays, which make them easily detected. Because previous release results showed moderate Eu release in hydrogen but almost none in steam, most of the europium release in test VI-6 (13.7\%) is believed to have occurred during Test Phase A (in hydrogen). Very little europium, which is relatively involatile under oxidizing conditions, has been released in tests in steam, but $13.4 \%$ was released in test VI-4 at $2440 \mathrm{~K}$ in hydrogen. As shown in Table 3.3, significant fractions (6.7 and 55\%, respectively) of the released $\mathrm{Sb}$ and Eu were deposited on ceramic surfaces in the outlet region of the furnace, where temperatures were believed to be 1500 to $2200 \mathrm{~K}$ during the test.

In order to calculate the release of cesium as a function of time, it is necessary to allocate the amount of cesium collected on the furnace components to the $A$,
$B$, and $C$ collection periods. The simplest method is to assume that the cesium deposited in the furnace was released from the fuel at the same rate as the cesium that was deposited in the A, B, and C collection systems. This is the method that was used with the ST-1 test, but it gave erroneous results for test VI-6. When this method was tried, the resulting release rates did not agree with those measured by the radiation detectors that were directed at the fuel rod itself, and it required unrealistic changes in efficiency for the radiation detector monitoring the thermal gradient tube and the top of the furnace.

The following procedure was used to calculate the amounts of vapor-form cesium and aerosol-associated cesium and the times that they were released from the fuel.

(1) All of the cesium deposited on the TGTs and on the $\mathrm{ZrO}_{2}$ plugs at the top of the furnace was assumed to have been in a vapor form before condensation or reaction with the $\mathrm{ZrO}_{2}$.

(2) All of the cesium collected on the filters and filter inlet lines was assumed to be aerosol associated.

(3) The amount of cesium deposited in the furnace inlet and exit regions was assumed to have a vapor/aerosol form ratio the same as the vapor/ aerosol ratio calculated from the total amounts in steps 1 and 2.

(4) The amount of aerosol-associated cesium calculated in step 3 was distributed to time periods $A, B$, and $C$ in direct proportion to the amounts calculated in step 2 .

(5) The amount of vapor-form cesium calculated for the furnace deposits in step 3 was allocated to time periods $\mathrm{A}, \mathrm{B}$, and $\mathrm{C}$ according to the radiation detector that monitored cesium deposition in the TGTs and the top of the furnace each minute during the test.

The results of this calculation are shown in Table 3.5 and Figure 3.5. The on-line radiation detectors are the NaI crystal type which permitted measurement of both ${ }^{134} \mathrm{Cs}$ and ${ }^{137} \mathrm{Cs}$. The ${ }^{134} \mathrm{Cs}$ data were used in preference to the ${ }^{137} \mathrm{Cs}$ data so that it was not necessary to 
Tabie 3.1 Summary of Eneion product relewee data for teat VI-6

\begin{tabular}{|c|c|c|c|c|c|c|}
\hline \multirow{2}{*}{ Location } & \multirow{2}{*}{$\begin{array}{c}\text { Operating time } \\
\text { at } T>2000 \mathrm{~K} \\
\text { (min) }\end{array}$} & \multicolumn{5}{|c|}{ Prection of fiecion product inventory found (\%)* } \\
\hline & & ${ }_{\mathbf{K} \mathbf{r}}$ & $w_{S b}$ & $m$ & ${ }^{m} a$ & ${ }^{14} \mathrm{En}$ \\
\hline Furnace components & 72 & 0 & 20.5 & 23.1 & 43.5 & 13.4 \\
\hline $\begin{array}{l}\text { Collection Train A: } \\
\text { TGT A } \\
\text { Filters } \\
\text { Total Train A }\end{array}$ & 6 & 42.0 & $\begin{array}{l}0.0 \\
0.0 \\
0.0\end{array}$ & $\begin{array}{c}3.50 \\
14.7 \\
18.2\end{array}$ & $\begin{array}{r}8.34 \\
5.37 \\
13.71\end{array}$ & $\begin{array}{l}0.0 \\
0.04 \\
0.04\end{array}$ \\
\hline $\begin{array}{l}\text { Collection Train B: } \\
\text { TGT B } \\
\text { Filters } \\
\text { Total Train B }\end{array}$ & 18 & 16.9 & $\begin{array}{l}0.0 \\
0.0 \\
0.0\end{array}$ & $\begin{array}{l}1.84 \\
2.04 \\
3.88\end{array}$ & $\begin{array}{l}2.57 \\
2.78 \\
5.35\end{array}$ & $\begin{array}{l}0.0 \\
0.001 \\
0.001\end{array}$ \\
\hline $\begin{array}{l}\text { Collection Train C } \\
\text { TGT C } \\
\text { Filters } \\
\text { Total Train C }\end{array}$ & 48 & 16.4 & $\begin{array}{r}8.35 \\
34.64 \\
42.99\end{array}$ & $\begin{array}{l}5.67 \\
16.1 \\
21.8\end{array}$ & $\begin{array}{r}8.91 \\
8.59 \\
17.50\end{array}$ & $\begin{array}{l}0.028 \\
0.167 \\
0.195\end{array}$ \\
\hline Total for test & 72 & 75.3 & 63.5 & 66.9 & 80.1 & 13.7 \\
\hline
\end{tabular}

-Inventories based on preteat gamma analyais of the fuel and ORIGEN2 calculatiois. 
Tuble 3.2 Cedium release and dibtribution data for teat VI-6

\begin{tabular}{|c|c|c|c|c|}
\hline \multirow[b]{2}{*}{ Location } & \multirow{2}{*}{$\begin{array}{l}\text { Approsimnte } \\
\text { temperature } \\
\text { (K) }\end{array}$} & \multicolumn{3}{|c|}{ Cesium found at each bocation* } \\
\hline & & $\begin{array}{l}{ }^{107} C \\
(m C)\end{array}$ & $\begin{array}{c}\text { Total C } \\
(\mathbf{m g})\end{array}$ & (\%) of inventory) \\
\hline $\begin{array}{l}\text { Purnsce components } \\
\text { Inlet region } \\
\text { First } \mathrm{ZrO}_{2} \text { plug } \\
\text { Second } \mathrm{ZrO}_{2} \text { plug } \\
\text { Ext region }\end{array}$ & $\begin{array}{c}500-1600 \\
\sim 2100 \\
\sim 1700 \\
500-1600\end{array}$ & $\begin{array}{r}208.0 \\
2.2 \\
1160.0 \\
1931.0\end{array}$ & $\begin{array}{r}5.99 \\
0.06 \\
33.43 \\
55.65\end{array}$ & $\begin{array}{r}2.742 \\
0.029 \\
15.291 \\
25.455\end{array}$ \\
\hline Total & & 3301.2 & 95.14 & 43.52 \\
\hline $\begin{array}{l}\text { Train A } \\
\text { TGT A } \\
\text { TGT - filter line } \\
\text { First prefilter } \\
\text { Second prefilter } \\
\text { HEPA filters }\end{array}$ & $\begin{array}{c}470-1000 \\
430 \\
405 \\
405 \\
405\end{array}$ & $\begin{array}{r}632.3 \\
72.1 \\
311.0 \\
22.8 \\
2.2\end{array}$ & $\begin{array}{r}18.22 \\
2.08 \\
8.96 \\
0.66 \\
0.06\end{array}$ & $\begin{array}{l}8.335 \\
0.950 \\
4.100 \\
0.301 \\
0.029\end{array}$ \\
\hline Total & & 1040.4 & 29.98 & 13.71 \\
\hline $\begin{array}{l}\text { Train B } \\
\text { TGT B } \\
\text { TGT - filter line } \\
\text { First prefilter } \\
\text { Second prefilter } \\
\text { HEPA filters }\end{array}$ & $\begin{array}{c}470-1070 \\
430 \\
410 \\
410 \\
410\end{array}$ & $\begin{array}{r}194.7 \\
23.4 \\
152.0 \\
33.4 \\
2.3\end{array}$ & $\begin{array}{l}5.61 \\
0.67 \\
4.38 \\
0.96 \\
0.07\end{array}$ & $\begin{array}{l}2.567 \\
0.308 \\
2.004 \\
0.440 \\
0.030\end{array}$ \\
\hline Total & & 405.8 & 11.70 & 5.35 \\
\hline $\begin{array}{l}\text { Train C } \\
\text { TGT C } \\
\text { TGT - filter line } \\
\text { First prefilter } \\
\text { Second prefilter } \\
\text { HEPA filters }\end{array}$ & $\begin{array}{c}407-1010 \\
430 \\
410 \\
410 \\
410\end{array}$ & $\begin{array}{r}675.5 \\
62.4 \\
582.5 \\
6.8 \\
0.6\end{array}$ & $\begin{array}{r}19.47 \\
1.80 \\
16.79 \\
0.20 \\
0.02\end{array}$ & $\begin{array}{l}8.905 \\
0.823 \\
7.679 \\
0.090 \\
0.008\end{array}$ \\
\hline Total & & 1327.8 & 38.27 & 17.50 \\
\hline Total released from fuel & & 6075 & 175 & 80.08 \\
\hline Total in fuel (after test) & & 1511 & 43.55 & 19.92 \\
\hline
\end{tabular}

-Inventory based on measured data: $7586 \mathrm{mCl}{ }^{19} \mathrm{Ca}$ on Juty 1, 1991; $0.02882 \mathrm{mg} \mathrm{Ca} / \mathrm{mCl}$ based on ORIGEN2. 
Table 3.3 Retention in furnace of cesium released from fuel in VI tests

\begin{tabular}{|c|c|c|c|c|c|c|}
\hline & \multicolumn{6}{|c|}{ Test No. } \\
\hline & V-1 & VI-2 & VI-3 & $\mathbf{V}-4^{\circ}$ & VI-5 & VI-6 \\
\hline $\begin{array}{l}\text { Test temperature (K) } \\
\text { Test atmosphere }\end{array}$ & $\begin{array}{l}\text { 2020/2300 } \\
\text { Steam }\end{array}$ & $\begin{array}{l}2300 \\
\text { Steam }\end{array}$ & $\begin{array}{l}2000 / 2700 \\
\text { Steam }\end{array}$ & $\begin{array}{c}2440 \\
\mathrm{H}_{2}\end{array}$ & $\begin{array}{c}2000 / 2720 \\
\mathrm{H}_{2}\end{array}$ & $\begin{array}{c}2310 \\
H_{2} / \text { steam }\end{array}$ \\
\hline $\begin{array}{l}\text { Released from fuel } \\
\text { (\% of fuel inventory) }\end{array}$ & 63.1 & 67.2 & 99.9 & 96.1 & 100 & 80.1 \\
\hline $\begin{array}{l}\text { Retained in furnace } \\
\text { (\% of fuel inventory) }\end{array}$ & 4.00 & 2.87 & 10.6 & 45.9 & 7.63 & 43.5 \\
\hline $\begin{array}{l}\text { Retained in furnace } \\
\text { (\% of release from fuel) }\end{array}$ & 6.34 & 4.27 & 10.6 & 47.1 & 7.63 & 54.3 \\
\hline
\end{tabular}

-The upper half of the furnace was intentionally cooled in teat VI-4 to duplicate the conditions of SNL teat ST-1. 
Table 3.4 Fractional release and distribution of antimony and europium in teat VI-6

\begin{tabular}{|c|c|c|c|c|c|c|}
\hline \multirow[b]{2}{*}{ Location } & \multicolumn{3}{|c|}{1256} & \multicolumn{3}{|c|}{${ }^{154} \mathrm{Bu}$} \\
\hline & $(\mathrm{mCl})$ & $\begin{array}{l}\text { (\% of } \\
\text { inventory) }\end{array}$ & $\begin{array}{c}\text { (\% of } \\
\text { released) }\end{array}$ & $(m C)$ & $\begin{array}{c}\text { (\%) of } \\
\text { inventory }\end{array}$ & $\begin{array}{c}\text { ( } \% \text { of } \\
\text { relensed) }\end{array}$ \\
\hline \multicolumn{7}{|l|}{ Furnace components } \\
\hline First $\mathrm{ZrO}_{2}$ plug & 0.236 & 0.796 & 1.255 & 20.014 & 12.635 & 92.416 \\
\hline Second $\mathrm{ZrO}_{2}$ plug & 3.670 & 12.386 & 19.511 & 1.103 & 0.696 & 5.091 \\
\hline Exit region & 2.170 & 7.324 & 11.536 & 0.159 & 0.100 & 0.734 \\
\hline Furnace total & 6.076 & 20.506 & 32.302 & 21.275 & 13.431 & 98.241 \\
\hline \multicolumn{7}{|l|}{ Train A } \\
\hline TGT A & 0.000 & 0.000 & 0.000 & 0.000 & 0.000 & 0.000 \\
\hline TGT - filter line & 0.000 & 0.000 & 0.000 & 0.028 & 0.018 & 0.130 \\
\hline First prefilter & 0.000 & 0.000 & 0.000 & 0.039 & 0.025 & 0.180 \\
\hline Second prefilter & 0.000 & 0.000 & 0.000 & 0.000 & 0.000 & 0.000 \\
\hline HEPA filters & 0.000 & 0.000 & 0.000 & 0.000 & 0.000 & 0.000 \\
\hline Train A total & 0.000 & 0.000 & 0.000 & 0.067 & 0.042 & 0.311 \\
\hline \multicolumn{7}{|l|}{ Train B } \\
\hline TGT B & 0.000 & 0.000 & 0.000 & 0.000 & 0.000 & 0.000 \\
\hline TGT - filter line & 0.000 & 0.000 & 0.000 & 0.002 & 0.001 & 0.000 \\
\hline First prefilter & 0.000 & 0.000 & 0.000 & 0.000 & 0.000 & 0.000 \\
\hline Second prefilter & 0.000 & 0.000 & 0.000 & 0.000 & 0.000 & 0.000 \\
\hline HEPA filters & 0.000 & 0.000 & 0.000 & 0.000 & 0.000 & 0.000 \\
\hline Train B total & 0.000 & 0.000 & 0.000 & 0.002 & 0.001 & 0.001 \\
\hline \multicolumn{7}{|l|}{ Train $\mathbf{C}$} \\
\hline TGT C & 2.474 & 8.350 & 13.153 & 0.046 & 0.029 & 0.212 \\
\hline TGT C - filter line & 0.997 & 3.365 & 5.300 & 0.030 & 0.019 & 0.138 \\
\hline Finst prefilter & 9.220 & 31.117 & 49.016 & 0.230 & 0.145 & 1.061 \\
\hline Second prefilter & 0.042 & 0.142 & 0.223 & 0.005 & 0.003 & 0.021 \\
\hline HEPA filters & 0.005 & 0.017 & 0.027 & 0.000 & 0.000 & 0.000 \\
\hline Train C total & 12.74 & 42.990 & 67.719 & 0.310 & 0.196 & 1.432 \\
\hline Total released from fuel & 18.81 & 63.50 & 100.02 & 21.655 & 13.671 & 99.98 \\
\hline Total in fuel (after test) & 10.82 & 36.52 & & 149.0 & 86.33 & \\
\hline
\end{tabular}

'Inventories baced on measured data: $29.63 \mathrm{mCi}{ }^{125} \mathrm{Sb}$ and $172.6 \mathrm{mCi}{ }^{14} \mathrm{Eu}$. 
Table 3.5 Physical form of released ceslum

\begin{tabular}{crcc}
\hline \multirow{2}{*}{$\begin{array}{c}\text { Colloction } \\
\text { period }\end{array}$} & \multicolumn{3}{c}{ Amount in designated form (\% of inventory) } \\
\cline { 2 - 4 } & Vapor & Aerosol & Total \\
\hline A & 37.4 & 9.5 & 46.9 \\
B & 7.1 & 5.0 & 12.1 \\
C & 5.8 & 15.3 & 21.1 \\
Total A+B+C & 50.3 & 29.8 & 80.1 \\
\hline
\end{tabular}

correct for the time delay caused by the "137" gamma being emitted from the ${ }^{137} \mathrm{Ba}$ daughter. Good agreement is evident between Figures 3.5 and 3.4, and between cesium and krypton in Figure 3.5.

\subsection{Analysis for Iodine}

Since iodine has no long-lived, gamma-emitting nuclides, analytical methods other than gamma spectrometry must be used to determine its behavior. Neutron activation of ${ }^{120} \mathrm{I}$ to ${ }^{130} \mathrm{I}$, which has abundant, easily measured gamma rays, is a proven and sensitive technique. Because the normally occurring iodine forms dissolve readily in basic solutions to form stable iodides, the collector components from this test were leached to remove this iodine for analysis.

The results of jodine analysis are summarized in Tables 3.1 and 3.6. As indicated, the total releases of $I$ and Cs were significantly different. Some $34 \%$ of the released ${ }^{129} \mathrm{I}$, compared to $54 \%$ of the released cesium, was deposited in the furnace. In addition, a larger fraction of the iodine was collected on the filters $(75 \%$ vs $25 \%$ on TGTs), compared to nearly equal fractions ( $46 \%$ on filters vs $54 \%$ on TGTs) for cesium, as shown in Table 3.7.

Some iodine forms (organic iodides, elemental iodine, or hydrogen iodide) may pass through the TGTs, penetrate the filters, and adsorb onto the heated charcoal in the filter packages. For this reason, the charcoal cartridges, which back up the filters, were analyzed for ${ }^{129} \mathrm{I}$ by direct activation also. The results of these analyses are shown in Table 3.8. The fraction of the released lodine that was collected on the charcoal (5.1\%) was higher in test VI-6 than in any previous test, which normally averaged $<0.5 \%$.

A possible source of the volatile iodine is radiation decomposition of an iodine species collected as particulate material on the glass wool and HEPA filters. Because the activated charcoal cartridges are part of the filter pack assembly and are located close to the highly radioactive filters, they would have received a relatively high radiation dose rate. In test VI-6, the filter/charcoal assembly remained sealed for 5 months after the test, a longer period than in most tests. This extended period of exposure possibly resulted in some decomposition of CsI, with the released iodine being sorbed on the nearby charcoal.

\subsection{Thermal Gradient Tube Deposits}

The three TGT liners were made by rolling 0.002 -in.thick stainless steel foil into tubes. Except for being annealed in $\mathrm{He}-4 \% \mathrm{H}_{2}$ to aid forming, the surfaces of the liners were in the as-received condition. These liners were removed from the surrounding Inconel TGTs and examined. During the test, each of the 36-cm-long TGT liners had been subjected to maximum temperatures of $\sim 850^{\circ} \mathrm{C}(1125 \mathrm{~K})$ at the inlet end. The TGT temperatures declined approximately linearly to $\sim 150^{\circ} \mathrm{C}$ at the exit end. All three liners showed evidence of external corrosion over the first few centimeters at the inlet ends, but the liner from TGT A (through which the furnace exit gas flowed during heatup and for the first $2 \mathrm{~min}$ at $2300 \mathrm{~K}$ ) was much more corroded than Liners B and C, from Phases $B$ and $C$ later in the test. This severe corrosion, to the extent that the first $\sim 5 \mathrm{~cm}$ of Liner $A$ 
Table 3.6 Iodine release and distribution data for test VI-6

\begin{tabular}{|c|c|c|c|}
\hline \multirow[b]{2}{*}{ Locntion } & \multirow{2}{*}{$\begin{array}{c}\text { Approximate } \\
\text { temperature } \\
\text { (K) }\end{array}$} & \multicolumn{2}{|c|}{ 1 found at cach location } \\
\hline & & $1(\mu 8)$ & Percent of inventory \\
\hline $\begin{array}{l}\text { Furnace components } \\
\text { Inlet region } \\
\text { First } \mathrm{ZrO}_{2} \text { plug } \\
\text { Second } \mathrm{ZrO}_{2} \text { plug } \\
\text { Exit region ceramics } \\
\text { Exit flange } \\
\text { Total }\end{array}$ & $\begin{array}{c}500-1600 \\
\sim 2100 \\
\sim 1700 \\
800-1600 \\
350-1100\end{array}$ & $\begin{array}{r}1 \\
0 \\
0 \\
400 \\
2574 \\
2975\end{array}$ & $\begin{array}{l}0.01 \\
0 \\
0 \\
3.11 \\
19.99 \\
23.11\end{array}$ \\
\hline $\begin{array}{l}\text { Train A } \\
\text { TGT A } \\
\text { TGT - filter line } \\
\text { First prefilter } \\
\text { Second prefilter } \\
\text { HEPA filters } \\
\text { Charcoal } \\
\text { Total }\end{array}$ & $\begin{array}{c}470-1000 \\
430 \\
405 \\
405 \\
405 \\
405\end{array}$ & $\begin{array}{r}451 \\
245 \\
1301 \\
0 \\
0 \\
339 \\
2337\end{array}$ & $\begin{array}{c}3.50 \\
1.90 \\
10.11 \\
0 \\
0 \\
2.63 \\
18.15\end{array}$ \\
\hline $\begin{array}{l}\text { Train B } \\
\text { TGT B } \\
\text { TGT - filter line } \\
\text { First prefilter } \\
\text { Second prefilter } \\
\text { HEPA filters } \\
\text { Charcoal } \\
\text { Total }\end{array}$ & $\begin{array}{c}470-1070 \\
430 \\
410 \\
410 \\
410 \\
410\end{array}$ & $\begin{array}{r}237 \\
18 \\
180 \\
0 \\
0 \\
64 \\
500\end{array}$ & $\begin{array}{l}1.84 \\
0.14 \\
1.40 \\
0 \\
0 \\
0.50 \\
3.88\end{array}$ \\
\hline $\begin{array}{l}\text { Train C } \\
\text { TGT C } \\
\text { TGT - filter line } \\
\text { First prefilter } \\
\text { Second prefilter } \\
\text { HEPA filters } \\
\text { Charcoal } \\
\text { Total }\end{array}$ & $\begin{array}{c}407-1010 \\
430 \\
410 \\
410 \\
410 \\
410\end{array}$ & $\begin{array}{r}730 \\
125 \\
1516 \\
0 \\
0 \\
428 \\
2799\end{array}$ & $\begin{array}{c}5.67 \\
0.97 \\
11.78 \\
0 \\
0 \\
3.33 \\
21.74\end{array}$ \\
\hline Total released from fuel & & 8611 & 66.89 \\
\hline
\end{tabular}

-Inventory based on ORIGEN2 calculation: $12.87 \mathrm{mg}{ }^{129} \mathrm{I}$ and 15.92 total iodine in fuel. 
Table 3.7 Comparison of physical forms of iodine and cesium released to collection trains

\begin{tabular}{ccccccc}
\hline & \multicolumn{3}{c}{ Frection in designated form (\% of element relessed from furnoc) } \\
\cline { 2 - 7 } Collection & \multicolumn{3}{c}{ Vapor } & \multicolumn{1}{c}{ Acrosol } & \multicolumn{2}{c}{ Total } \\
\cline { 2 - 7 } period & I & C. & \multicolumn{1}{c}{ I } & C. & I & C. \\
\hline A & 8.0 & 22.8 & 33.6 & 14.7 & 41.6 & 37.5 \\
B & 4.2 & 7.0 & 4.7 & 7.6 & 8.9 & 14.6 \\
C & 13.0 & 24.3 & 36.8 & 23.5 & 49.8 & 47.8 \\
Total A+B+C & 25.2 & 54.1 & 75.1 & 45.8 & 100.3 & 99.9 \\
\hline
\end{tabular}

-Breed on total inventory in the fuel, $43.8 \%$ of the iodine and $36.6 \%$ of the cesium were released from the furnace.

Table 3.8 Volatile iodine in test V1-6

\begin{tabular}{|c|c|c|}
\hline \multirow[b]{2}{*}{ Sample No. } & \multicolumn{2}{|c|}{ Volatile iodine* } \\
\hline & Mass (ug) & Percent of released ${ }^{+}$ \\
\hline AC1 & 339 & 2.1 \\
\hline $\mathrm{AC2}$ & 0.1 & 0.0 \\
\hline AC3 & ND** & 0.0 \\
\hline BC1 & 64 & 0.4 \\
\hline $\mathrm{BC} 2$ & ND & 0.0 \\
\hline $\mathrm{BC3}$ & ND & 0.0 \\
\hline CC1 & 428 & 2.6 \\
\hline $\mathrm{CC2}$ & 0.1 & 0.0 \\
\hline $\mathrm{CC3}$ & ND & 0.0 \\
\hline Totals & 831 & 5.1 \\
\hline
\end{tabular}

-As determined by measurements of ${ }^{29} \mathrm{I}$.

"ND = Not Detected.

+Assumes that total iodine release is the same as the cesium release, $80.09 \%$ of total inventory. 
disintegrated during removal, indicated that the material released from the furnace during Phase $A$ was more corrosive than that released later in the test. Upon opening the liners, the internal deposits in Liner $A$ appeared to be uniformly distributed and heavier than those in Liner B, but not as heavy as those in Liner $\mathbf{C}$.

The collection of cesium on the stainless steel TGT liners was monitored during the test by counting the ${ }^{134} \mathrm{Cs}$ and ${ }^{137} \mathrm{Cs}$ continuously. The final ${ }^{137} \mathrm{Cs}$ profiles, as well as the temperature profile along the TGTs, are shown in Figure 3.6. Although small amounts of ${ }^{125} \mathrm{Sb}$ (in TGT C) and ${ }^{154} \mathrm{Eu}$ (in TGTs $A$ and C) were present, as measured by long counts and shown in Table 3.4, the profiles could not be measured concurrently with the ${ }^{137} \mathrm{Cs}$ profile. The fact that most of the cesium released during Test Phase B was in vapor form, as indicated by its deposition on TGT Liner B rather than on Filter B, confirms that little steam was present during this period. (Previous tests have shown that in a steam atmosphere, $\sim 70 \%$ of the released cesium is transported as aerosols, which are collected primarily on the filters.') Only when full steam flow through the furnace was established (at $93 \mathrm{~min}$ ) did most of the cesium pass through the TGTs to be collected on the filters, presumably as oxide or hydroxide forms.

\subsection{Masses of Deposits in TGTS and on Filters}

The filters and TGT liners were weighed before and after the test to determine the mass of material collected. Most of the material deposited in the TGT liners is believed to be a result of vapor condensation, and the material deposited on the filters probably was transported primarily as aerosol. Immediately after disassembly of the filter packages, the filters were inspected and packaged for weighing. Although the prefilters exhibited light deposits, no deposits were visible and no weight changes were observed for the HEPA filters, indicating efficient collection of the aerosols by the prefilters.

The masses of material collected at the various locations are listed in Table $\mathbf{3 . 9}$ and illustrated in Figure 3.7. Because of the disintegration of the inlet end of Liner $A$, as mentioned above, an accurate weight was impossible. Based on the relative appearances of the test VI-6 liners, and on measurements from other tests, we estimated that Liner A contained $\sim 100 \mathrm{mg}$ of deposits.

As would be expected, the greatest mass was collected during Phase $\mathrm{C}$, the longest collection period, and also the period of steam flow. (Previous tests, such as VI-3 and VI-5, have shown that mass releases are much greater in steam than in hydrogen.) The total mass collected $(0.573 \mathrm{~g})$ was much less than in the all-steam atmosphere test VI-2 (1.134 g) at the same temperature and time. Since $68 \%$ of the released mass $(0.391 \mathrm{~g})$ was found in Train C, the period with steam atmosphere, test VI- 6 behavior was consistent with earlier tests.

\subsection{ICP-ES Analyses}

Samples of the acidic leach solutions from the TGT liners and the filters were submitted for inductively coupled plasma-emission spectrometry (ICP-ES) analyses for non-gamma-emitting elements. This technique is well suited for measuring several of the fission product elements, primarily cations, and uranium. Unfortunately, it is not useful for iodine analysis. Because of the high levels of radiocesium in most of the samples, large dilutions, which reduced the precision of the measurements, have been required to avoid excess radiation dose to the analyst.

As would be expected, major release fractions of all these elements were retained in the outlet end of the furnace, where the time (Test Phase A, B, or C) of release and/or deposition cannot be determined. Furthermore, the largest fractions of these four elements that were released to the collection trains were found in Train $\mathrm{C}$, as shown in Table 3.10. The large: fractions in Train $\mathrm{C}$ are consistent with the steam atmosphere during that period, which tended to accelerate release by oxidizing the $\mathrm{UO}_{2}$, and the longer period of operation, $40 \mathrm{~min}$ as opposed to $2 \mathrm{~min}$ and $18 \mathrm{~min}$ at $2300 \mathrm{~K}$ for Trains $\mathrm{A}$ and $\mathrm{B}$, respectively.

Because of their well-known sensitivity to the effects of oxidizing conditions, most of the release of Mo and $\mathrm{Te}$ is believed to have occurred during the latter part of Phase $\mathrm{C}$, after the cladding had been oxidized by the steam. The observed behavior of these four lessvolatile fission product elements is in general 
공

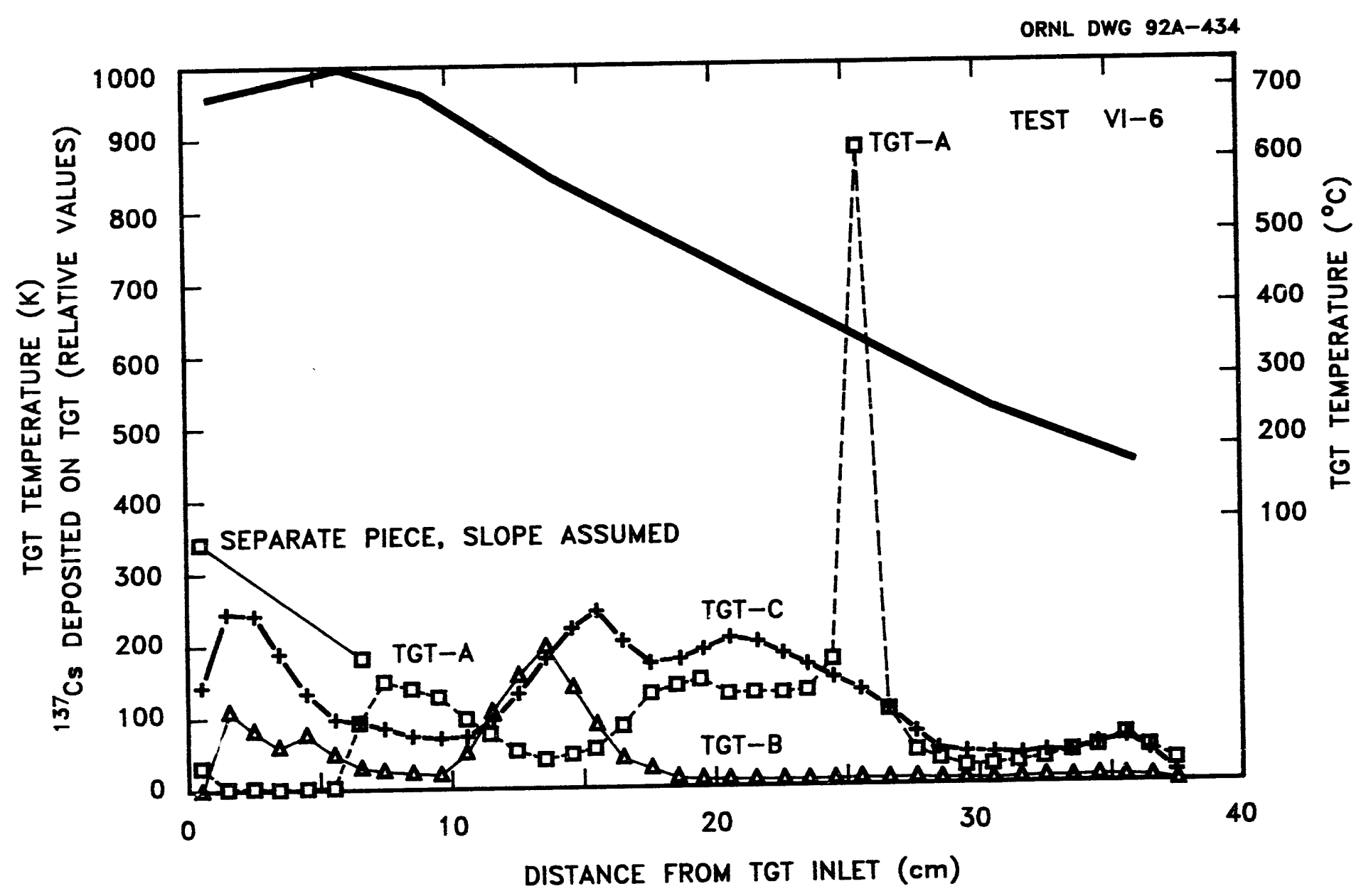

Figure 3.6 Distributions of ${ }^{137} \mathrm{CS}$ along thermal gradient tubes A, B, and C in test VI-6. Note temperature profile also 
Table 3.9 Vapor and aerosol deposits in test VI-6

\begin{tabular}{lcccc}
\hline & \multicolumn{4}{c}{ Weight of deposits (g)* } \\
\cline { 2 - 5 } & Train A & Train B & Train C & Total \\
\hline Thermal gradient tube (TGT) & $0.100^{* *}$ & 0.031 & 0.161 & 0.292 \\
Filters & & & & \\
Prefilter 1+ & 0.036 & 0.015 & 0.230 & 0.281 \\
Prefilter 2 & 0.000 & 0.000 & 0.000 & 0.000 \\
HEPAs & 0.000 & 0.000 & 0.000 & 0.000 \\
Total filters & 0.036 & 0.015 & 0.230 & 0.281 \\
Total TGT and filters & 0.136 & 0.046 & 0.391 & 0.573 \\
\hline
\end{tabular}

- Precision $= \pm 0.003 \mathrm{~g}$.

"Estimated value; inlet end of TGT A was corroded and disintegrated.

+ Includes estimated mass of deposits in connecting tubes, based on ${ }^{157} \mathrm{Cs}$ data. 


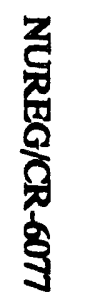

ORNL DWG 92A-433

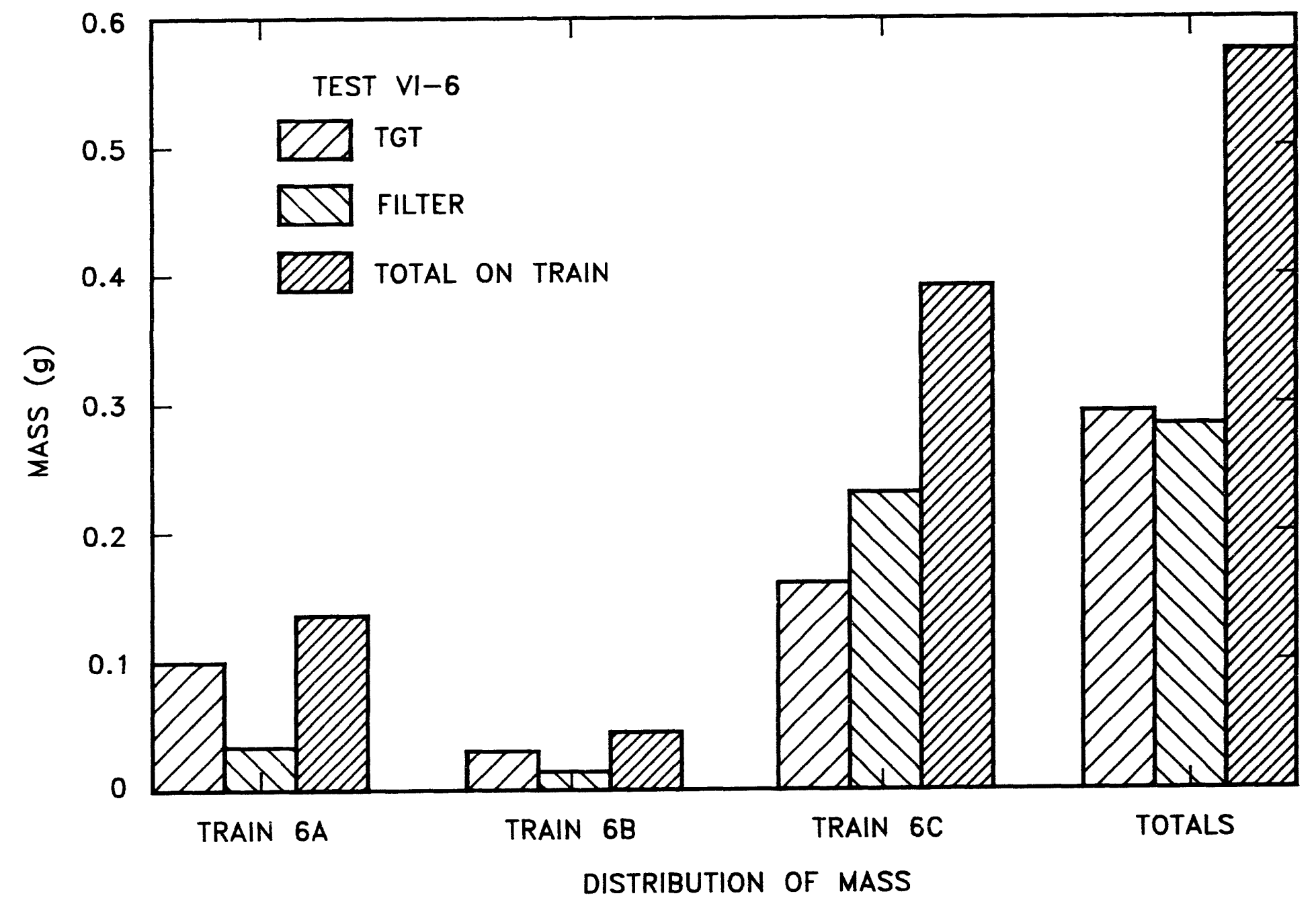

Figure 3.7 Mass distribution to the collection system of matei ial released during test VI-6 
Table 3.10 Test VI-6 release data for less-volatile fission products

\begin{tabular}{|c|c|c|c|c|c|}
\hline \multirow[b]{2}{*}{ Location } & \multirow{2}{*}{$\begin{array}{c}\text { Time fuel at } \\
2300 \mathrm{~K} \text { (min) }\end{array}$} & \multicolumn{4}{|c|}{ Release (\% of inventory) } \\
\hline & & Sr & Mo & Te & Ba \\
\hline Furnace & 60 & 5.50 & 12.2 & 40.7 & 29.0 \\
\hline Train A & 2 & 0.087 & 0.015 & 1.80 & 1.10 \\
\hline Train B & 18 & 0.063 & 0.008 & 1.43 & 0.817 \\
\hline Train C & 40 & 0.171 & 0.40 & 19.5 & 1.45 \\
\hline Totals & & 5.82 & 12.6 & 63.4 & 32.4 \\
\hline
\end{tabular}

agreement with the CORSOR model and with other experimental data. ${ }^{14}$

\subsection{Modeling of Volatile Fission Product Release}

Because the ${ }^{85} \mathrm{Kr},{ }^{134} \mathrm{Cs}$, and ${ }^{137} \mathrm{Cs}$ were collected and measured on-line at 1-min intervals during the test, calculation of the minute-by-minute release rates was readily accomplished. As in previous tests, the release behaviors of $\mathrm{Kr}$ and $\mathrm{Cs}$ were similar, including the transition period from hydrogen (reducing) to steam (oxidizing) atmospheres.

The on-line data for $\mathrm{Kr}$ and $\mathrm{Cs}$ were used to calculate the minute-by-minute diffusion coefficients during test VI-6, and the ${ }^{85} \mathrm{Kr}$ diffusion coefficients are plotted vs temperature in Figure 3.8. Good agreement with a curve representing the ORNL Diffusion Model is apparent, and the agreement of Cs data with the model was comparable. This model, which uses data from previous tests, most of which were in steam, and includes the effects of grain size and burnup, has been described elsewhere. ${ }^{7}$ As may be seen in Figure 3.8, the values from test VI-6 fall somewhat above the curve at the lowest temperatures $(<1500 \mathrm{~K})$. This release is believed to result from a combination of poor counting statistics and surface desorption of nuclides released and adsorbed during irradiation, rather than from diffusion from the fuel matrix. The vertical cluster of points at $2300 \mathrm{~K}$ reflects the decline in release rate with time, as a result of source depletion, at the constant test temperature. A plot of the same diffusion coefficients for ${ }^{85} \mathrm{Kr}$ as a function of time is presented in Figure 3.9. The decline in diffusion coefficient during the period of low steam flow ( $~ 55$ to $93 \mathrm{~min}$ ) and the increase in diffusion coefficient with increased steam flow are apparent in this figure. 
ORNL DWG 92A-721

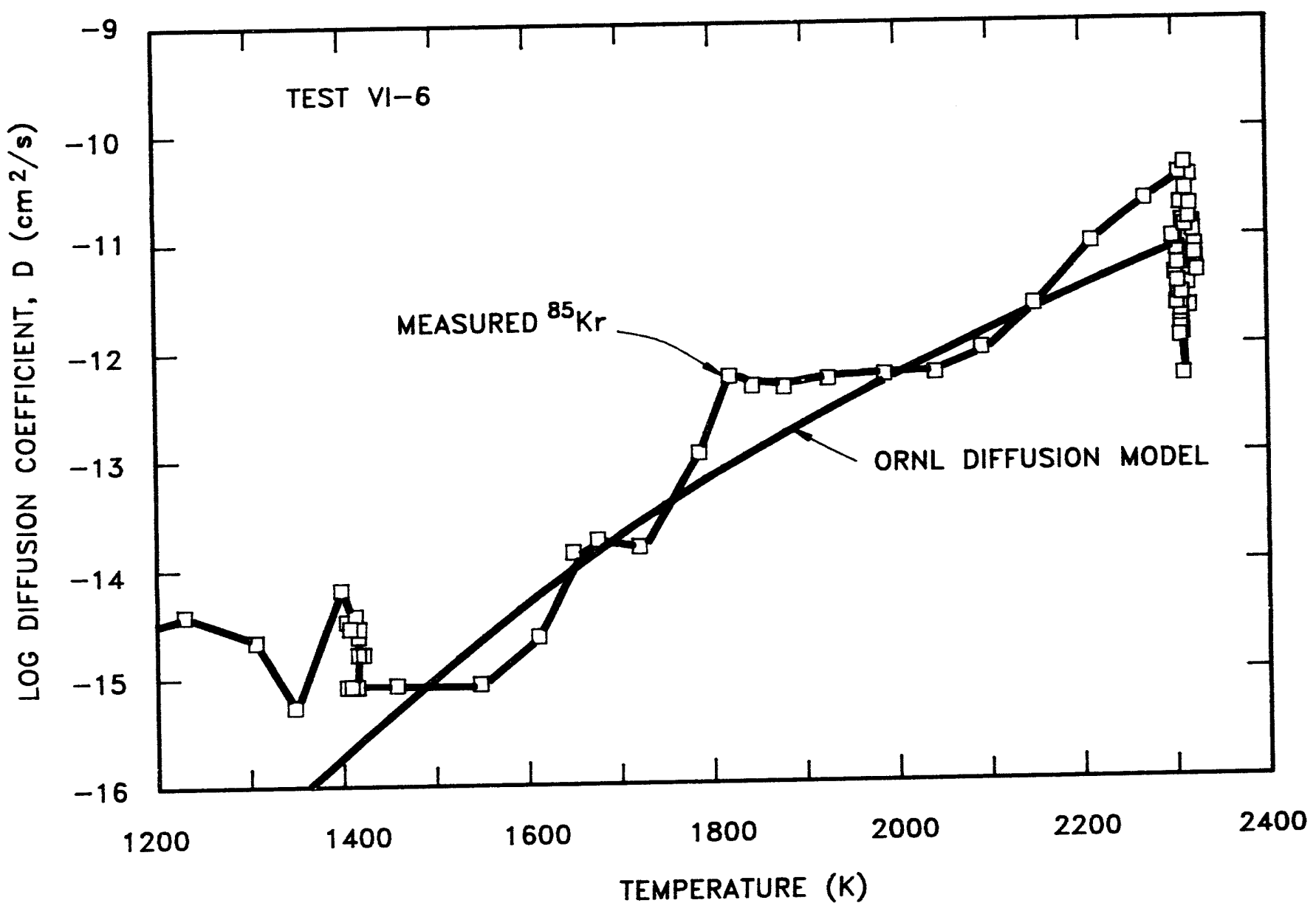

Figure 3.8 Diffusion coefficients for ${ }^{85} \mathrm{Kr}$, as calculated from minute-by-minute release data, in test VI-6. Note decline in diffusion coefficients with source depletion at test temperature $(2310 \mathrm{~K})$ 
ORNL DWG 92A-719

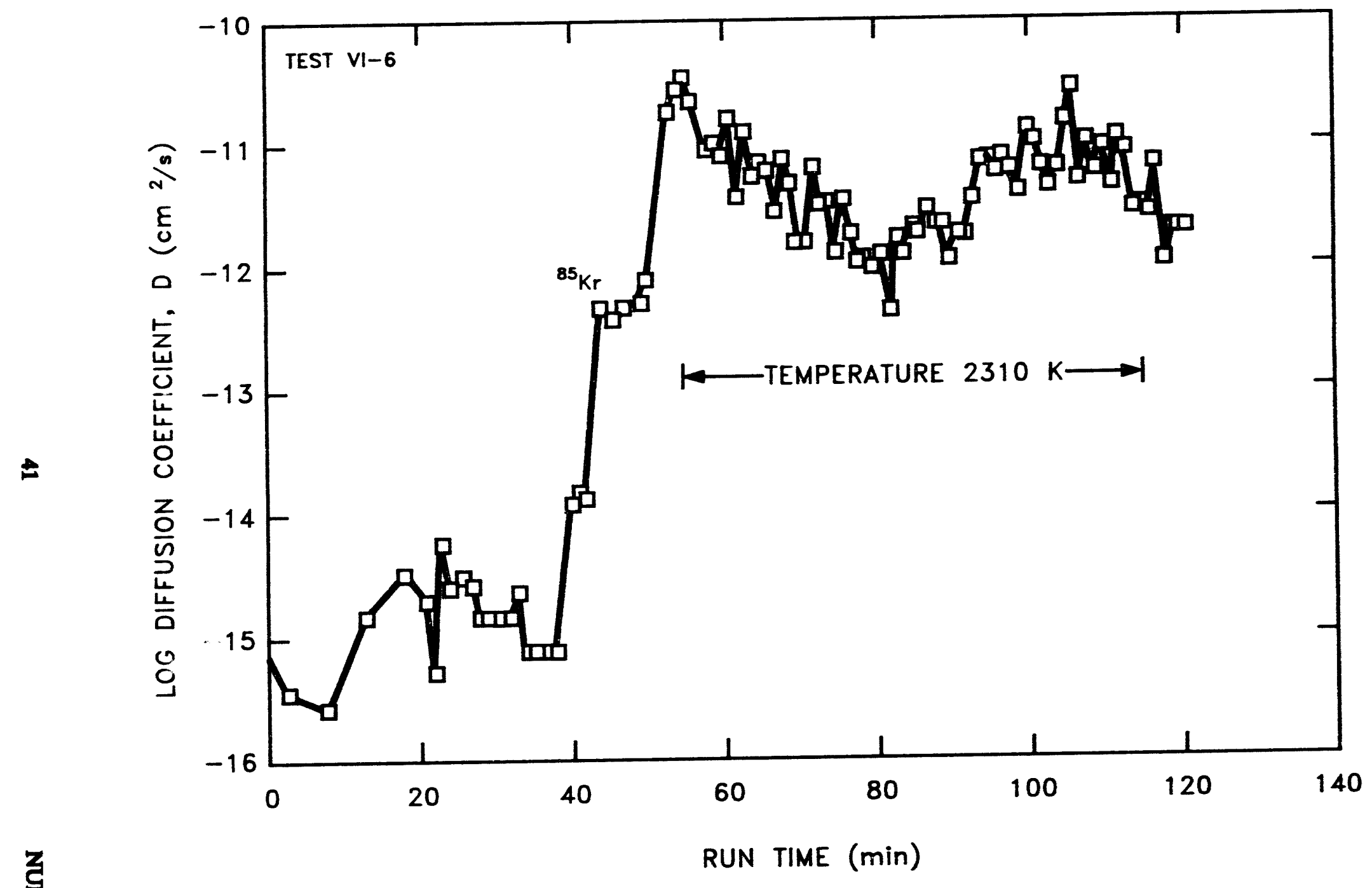

Figure 3.9 Diffusion coeficients for ${ }^{\circ} \mathrm{Kr}$ at constant test temperature (2310 $\left.\mathrm{K}\right)$ in test VI-6 


\section{Comparison of Release Data with Previous Results}

The fission product release data from this test (VI-6) have been compared with the results from earlier experiments and also with results from an earlier comprehensive NRC review of all relevant fission product release data, which was the basis for the CORSOR model. ${ }^{\text {is }}$ Because test VI-6 was essentially identical to test VI-2 except for the change in atmosphere, we were particularly interested in comparing the results from these two tests.

The integral release data for nine fission product elements from test VI-6 are compared with results of previous tests of BR3 fuel (VI-2, VI-3, VI-4, and VI-5) in Table 4.1. The VI-6 data, with test phase differentiation, arc plotted in Figure 4.1. For Figure 4.1, the release of furnace-deposited material was assumed to be at the same relative rate as material collected in systems A, B, and C. The fractional releases of krypton and cesium were always similar, except for the lower krypton value for test VI-2, where some of the gas was known to have been lost, and exhibited a general increase with test temperature, reaching $\sim 100 \%$ at $2700 \mathrm{~K}$. The release behavior of iodine is believed to be similar to that of krypton and cesium; the somewhat lower values for lodine shown in Table 4.1 can be explained by the problems of thorough sampling and neutron activation analysis. No significant influence of the reactive atmospheres, steam and hydrogen, on the release of these highly volatile elements was apparent.

With regard to atmospheric effects on the less-volatile species, the recent data supported the conclusions drawn from earlier results. ${ }^{1217}$ The release behaviors of $\mathrm{Sb}, \mathrm{Sr}, \mathrm{Mo}, \mathrm{Te}, \mathrm{Ba}$, and $\mathrm{Eu}$, on the other hand, showed a clear influence of the reactive atmospheres, and these atmospheric effects became more exaggerated at the highest temperature, $2700 \mathrm{~K}$. Much higher release of $\mathrm{Sb}$ and Mo was observed in steam, whereas $\mathrm{Ba}, \mathrm{Sr}$, and $\mathrm{Eu}$ releases were higher in hydrogen. The data for Te appear inconsistent; incomplete sampling and analysis, as well as some uncertainties about the oxidation conditions, are believed to be the main problems in interpreting Te behavior. In conclusion, the behaviors of these elements in test VI- 6 were found to be generally consistent with their chemical characteristics. 
Table 4.1 Comparieon of fiesion product release data for $V$ tests

\begin{tabular}{|c|c|c|c|c|c|}
\hline & \multicolumn{5}{|c|}{ Teat No. } \\
\hline & VI-2 & VI-3 & $\mathbf{n}-4$ & VI-5 & VI-6 \\
\hline $\begin{array}{l}\text { Teat conditions } \\
\text { Test temperature (K) } \\
\text { Time at temp. (min) } \\
\text { Atmosphere. }\end{array}$ & $\begin{array}{c}230 \\
60 \\
\text { Steam }\end{array}$ & $\begin{array}{l}2000 / 2700 \\
20 / 20 \\
\text { Steam }\end{array}$ & $\begin{array}{c}2400 \\
20 \\
\text { Hydrogen }\end{array}$ & $\begin{array}{c}2015 / 2740^{*} \\
20 / 20 \\
\text { Hydrogen }\end{array}$ & $\begin{array}{c}2310 \\
60 \\
\text { Hydrogen/steam }\end{array}$ \\
\hline Fincion product relene & \multicolumn{5}{|c|}{ (\% Release from fuel) } \\
\hline $\begin{array}{l}{ }^{85 r} \\
{ }^{125} \mathrm{Sb} \\
{ }^{125} \\
{ }^{137} \mathrm{Cs} \\
\mathrm{Sr} \\
\mathrm{Mo} \\
\mathrm{Te} \\
\mathrm{Ba} \\
{ }^{134} \mathrm{Eu}\end{array}$ & $\begin{array}{r}>31 \\
68 \\
40 \\
67 \\
\text { ND }^{+} \\
86 \\
>50 \\
19 \\
0\end{array}$ & $\begin{array}{c}100 \\
99 \\
69 \\
100 \\
2.7 \\
77 \\
100 \\
30 \\
\sim 0.01\end{array}$ & $\begin{array}{c}94 \\
6.4 \\
87 \\
96 \\
++ \\
7 \\
<46 \\
27 \\
19\end{array}$ & $\begin{array}{c}100 \\
18 \\
++ \\
100 \\
34 \\
2.3 \\
82 \\
75 \\
57\end{array}$ & $\begin{array}{c}75 \\
64 \\
67 \\
80 \\
5.8 \\
13 \\
63 \\
32 \\
14\end{array}$ \\
\hline
\end{tabular}

-Teats VI-3 and VI-5 were cunducted in two phases at two different temperatures.

- In all tests, the reactive atmosphere was mixed with helium.

+ ND $=$ Not Detected.

++ Analyair incomplete.

†Extrapolated from limited data. 


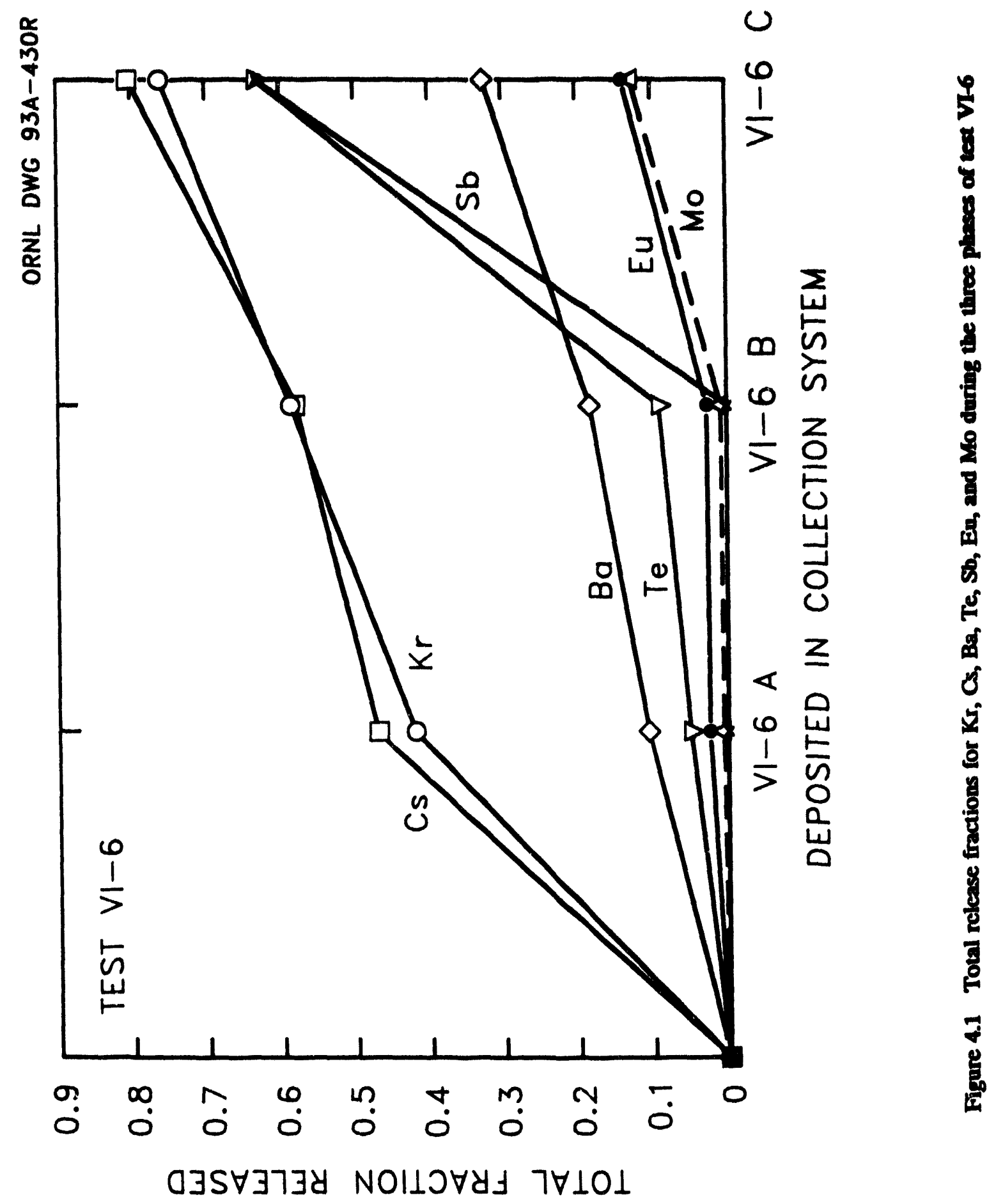




\section{Summary and Conclusions}

In view of the preliminary nature of this report and the fact that some important analyses/results have not yet been obtained, a thorough interpretation of the results of test VI-6 is not possible at this time. However, several significant observations are appropriate.

(1) This was the second test at $2300 \mathrm{~K}$ for $60 \mathrm{~min}$ and the first test in which the atmosphere was changed from hydrogen to steam in mid-test. With the exception of the delay in establishing design steam flow through the furnace after hydrogen flow was stopped, the test was conducted as planned. Examination showed that the Zircaloy cladding had melted during the heatup in hydrogen and that only minimal collapse or rundown of the $\mathrm{UO}_{2}$ fuel had occurred.

(2) The release values for many of the fission products were determined for the specific conditions of this test. The integral release values were $75 \%$ for $\mathrm{Kr}, \mathbf{8 0 \%}$ for $\mathrm{Cs}, \mathbf{6 7 \%}$ for I, $64 \%$ for $\mathrm{Sb}, \mathbf{6 3 \%}$ for $\mathrm{Te}, 32 \%$ for $\mathrm{Ba}, 5.8 \%$ for $\mathrm{Sr}, 13 \%$ for $\mathrm{Mo}$, and $14 \%$ for Eu. Comparison of these release values with the results from previous tests showed generally consistent behavior of the fission products. The fractional release measurements for iodine will be completed and reported later.

(3) Compared to previous tests, a larger fraction of the released fission products (32\% of the $\mathrm{Sb}, 54 \%$ of the $\mathrm{Cs}$, and $98 \%$ of the $\mathrm{Eu}$ ) deposited on the $\mathrm{ZrO}_{2}$ ceramics in the outlet end of the furnace.

(4) The total mass of deposits collected on the TGTs and the filters $(0.57 \mathrm{~g})$ was only $51 \%$ of that collected in test VI-2, which experienced the same temperature-time history. Most of this release occurred during Test Phase $\mathrm{C}$, confirming previous observations of much higher mass release rates in steam than in hydrogen.

(5) Approximately $5.1 \%$ of the released iodine was collected on the charcoal filter cartridges, indicating it had been in a volatile form $-\mathrm{I}_{2}, \mathrm{HI}$, and/or $\mathrm{CH}_{3} \mathrm{I}$. This relatively high fraction is believed to result from radiation decomposition of more stable forms, such as CsI.

(6) As in all previous tests, the release behaviors of the volatile species $(\mathrm{Kr}, \mathrm{I}$, and $\mathrm{Cs})$ were very similar in test VI-6. In addition, the diffusion coefficients for $\mathrm{Kr}$ and $\mathrm{Cs}$ calculated from on-line release data were in good agreement with the ORNL Diffusion Model.

(7) The fractional releases of several less-volatile fission product elements were found to be significant, varying from $5.8 \%$ for $\mathrm{Sr}$ to $63 \%$ for Te. 


\section{References}

1. Osborne, M. F., J. L. Collins, and R. A. Lorenz, "Experimental Studies of Fission Product Release from Commercial LWR Fuel Under Accident Conditions," Nucl. Technol. 78(2):157-69, August 1987.

2. Osborne, M. F., J. L. Collins, R. A. Lorenz, J. R. Travis, C. S. Webster, and T. Yamashita, "Data Summary Report for Fission Product Release Test VI-1," NUREG/CR-5339 (ORNL/TM-11104), Oak Ridge National Laboratory, June 1989.

3. Osborne, M. F., J. L. Collins, R. A. Lorenz, J. R. Travis, and C. S. Webster, "Data Summary Report for Fission Product Release Test VI-2," NUREG/ CR-5340 (ORNL/TM-11105), September 1989.

4. Osborne, M. F., J. L. Collins, R. A. Lorenz, J. R. Travis, C. S. Webster, S. R. Daish, H. K. Lee, T. Nakamura, and Y.-C. Tong, "Highlights Report for Fission Product Release Test VI-3," draft letter report to SFD Partners, July 1987.

5. Osborne, M. F., R. A. Lorenz, J. L. Collins, J. R. Travis, C. S. Webster, and T. Nakamura, "Data Summary Report for Fission Product Release Test VI-4," NUREG/CR-5481 (ORNL/TM-11400), Oak Ridge National Laboratory, January 1991.

6. Osborne, M. F., R. A. Lorenz, J. R. Travis, C. S. Webster, and J. L. Collins, "Data Summary Report for Fission Product Release Test VI-5," ORNL/ CR-5666 (ORNL/TM-11743), Oak Ridge National Laboratory, draft, December 1990.

7. Osborne, M. F., and R. A. Lorenz, "ORNL Studies of Fission Product Release Under LWR Accident Conditions," Nuclear Safety, 33(3):344-65, JulySept. 1992.

8. Osborne, M. F., and R. A. Lorenz, "Fission Product Release at Severe Accident Conditions: FY 1989 Program Plan," ORNL/NRC/LTR-89/2, April 1989.

9. Lorenz, R. A., J. L. Collins, and S. R. Manning, "Fission Product Release from Simulated LWR Fuel," NUREG/CR-0274 (ORNL/TM-154), Oak Ridge National Laboratory, October 1978.
10. Osborne, M. F., J. L. Collins, P. A. Haas, R. A. Lorenz, J. R. Travis, and C. S. Webster, "Design and Final Safety Analysis Report for Vertical Furnace Fission Product Release Apparatus in Hot Cell B, Building 4501," NUREG/CR-4332 (ORNL/TM-972C), Oak Ridge National Laboratory, March 1986.

11. Croff, A. G., "ORIGEN2 - A Revised and Updated Version of the Oak Ridge Isotope Generation and Depletion Code," ORNL-5621, Oak Ridge National Laboratory, July 1980.

12. Lorenz, R. A, et al., "Prompt Release of Fission Products from Zircaloy-Clad UO ${ }_{2}$ Fuels," Sect. 1 in Nuclear Safety Program Annual Progress Report for the Period Ending December 31, 1867, ORNL-4228, Oak Ridge National Laboratory, April 1968.

13. Collins, J. L., M. F. Osborne, R. A. Lorenz, and A. P. Malinauskas, "Fission Product Iodine and Cesium Release Behavior Under Severe LWR Accident Conditions," Nucl. Technol. 81(10):78-94 (1987).

14. Kuhlman, M. R., D. J. Lehmicke, and R. O. Meyer, "CORSOR User's Manual," NUREG/CR4173 (BMI-2122), Battelle Memorial Institute, March 1985.

15. U.S. Nuclear Regulatory Commission, Technical Bases for Estimating Fission Product Behavior During LWR Accidents," NUREG-0772, June 1981.

16. Osborne, M. F., R. A. Lorenz, and J. L. Collins, "Atmospheric Effects on Fission Product Behavior at Severe Accident Conditions," Proc. Am. Nucl. Soc. Int'L. Top. Mtg. on the Safety of Thermal Reactors, Portland, OR, July 21-25, 1991.

17. Osborne, M. F., and R. A. Lorenz, "Results of ORNL VI Series Fission Product Release Tests," Proceedings of Twentieth Water Reactor Safety Information Meeting, Bethesda, MD, October 2123, 1992. 
NUREG/CR-6077

ORNL/TM-12416

Dist. Category R3

\section{INTERNAL DISTRIBUTION}

1. F. Barrera

2. E. C. Beahm

3. J. T. Bell

4. A. Boatman

5. C. W. Chase

6. J. L. Collins

7. T. A. Dillow

8. B. Z. Egan

9. W. Fulkerson

10. W. A. Gabbard

11. R. K. Genung

12. S. R. Greene

13. E. K. Johnson

14. T. S. Kress

15-19. R. A. Lorenz

20. A. P. Malinauskas
21-25. M. F. Osborne

26. G. W. Parker

27. C. E. Pugh

28. D. R. Reichle

29. J. C. Rudolph

30. R. P. Taleyarkhan

31. J. R. Travis

32. C. S. Webster

33. A L. Wright

34. Central Research Library

35. ORNL-Y-12 Technical Library Document Reference Section

36-37. Laboratory Records

38. Laboratory Records, ORNL RC

39. ORNL Patent Section

\section{EXTERNAL DISTRIBUTION}

40. Office of Assistant Manager for Energy Research and Development, ORO-DOE, P.O. Box 2001, Oak Ridge, TN 37831

41. Director, Division of Reactor Safety Research, U.S. Nuclear Regulatory Commission, Washington, DC 20555

42-43. Office of Scientific and Technical Information, P.O. Box 2001, Oak Ridge, TN 37831

44-45. A. Behbahani, Accident Evaluation Branch, U.S. Nuclear Regulatory Commission, 5650 Nicholson Lane, Rockville, MD 20852

46. R. Y. Lee, U.S. Nuclear Regulatory Commission, Office of Nuclear Regulatory Research, NL344, Washington, DC 20555

47. R. Barrett, U.S. Nuclear Regulatory Commission, Office of Nuclear Reactor Regulation, OWFN, MS-8H7, Washington, DC 20555

48. J. H. Flack, U.S. Nuclear Regulatory Commission, Office of Nuclear Reactor Regulation, NLS324, Washington, DC 20555

49. L. Soffer, U.S. Nuclear Regulatory Commission, Office of Nuclear Reactor Regulation, NLS324, Washington, DC 20555

50. A. C. Thadani, U.S. Nuclear Regulatory Commission, Office of Nuclear Reactor Regulation, OWFN 8E2, Washington, DC 20555

51. E. S. Beckjord, U.S. Nuclear Regulatory Commission, Office of Nuclear Regulatory Research, NLS007, Washington, DC 20555

52. F. Eltawila, Accident Evaluation Branch, Office of Nuclear Regulatory Research, NLN344, Washington, DC 20555

53. N. Grossman, U.S. Nuciear Regulatory Commission, Office of Nuclear Regulatory Research, NLN344, Washington, DC 20555

54. T. L. King, U.S. Nuclear Regulatory Commission, Office of Nuclear Regulatory Research, NLN370, Washington, DC 20555 
55. R. L. Palla, Jr., U.S. Nuclear Regulatory Commission, Office of Nuclear Regulatory Research, OWFN 10 E 4, Washington, DC 20555

56. B. W. Sharon, U.S. Nuclear Regulatory Commission, Office of Nuclear Regulatory Research, NLN369, Washington, DC 20555

57. T. P. Speis, U.S. Nuclear Regulatory Commission, Office of Nuclear Regulatory Research, NLS007, Washington, DC 20555

58. G. C. Tinkler, U.S. Nuclear Regulatory Commission, Office of Nuclear Regulatory Research, NLN344, Washington, DC 20555

59. M. D. Houston, U.S. Nuclear Regulatory Commission, Office of A_RS, PHIL P-315, Washington, DC 20555

60. A. M. Rubin, U.S. Accident Evaluation Branch, Office of Nuclear Regulatory Research, NLN344, Washington, DC 20555

61. B. Spencer, Argonne National Laboratory, 9700 South Cass Avenue, Argonne, IL 60439

62. W. H. Rettig, U.S. Department of Energy, Idaho Operations Office, 785 DOE Place, Idaho Falls, ID 83401-1134

63. C. Alexander, Battelle Columbus Laboratory, 505 King Avenue, Columbus, OH 43201

64. T. Pratt, Brookhaven National Laboratory, 130 BNL, Upton, NY 11973

65. M. Merilo, Electric Power Research Institute, P.O. Box 10412, 3412 Hillview Avenue, Palo Alto, CA 94304

66. R. J. Hammerslcy, Fauske and Associates, Inc., 16WD70 West 83rd Street, Burr Ridge, IL 60521

67. F. E. Panisko, Reactor Systems, Fuels \& Materials, P8-35, Pacific Northwest Laboratory, P.O. Box 999, Richland, WA 99352

68. N. Bixler, Sandia National Laboratory, P.O. Box 5800, Albuquerque, NM 87185

69. D. Powers, Sandia National Laboratory, P.O. Box 5800, Albuquerque, NM 87185

70. S. Thompson, Sandia National Laboratory, P.O. Box 5800, Albuquerque, NM 87185

71. K. Washington, Sandia National Laboratory, P.O. Box 5800, Albuquerque, NM 87185

72. K. O. Reil, Sandia National Laboratory, P.O. Box 5800, Albuquerque, NM 87185

73. I. Catton, University of California Los Angeles, Nuclear Energy Laboratory, 405 Hilgard Avenue, Los Angeles, CA 90024

74. C. M. Allison, Idaho National Engineering Laboratory, EG\&G Idaho, Inc., P.O. Box 1625, MS 3840, Idaho Falls, ID 83415

75. R. Schneider, ABB/CE, 1000 Prospect Mill Road, CEP 9612-2207, Winsor, CT 06095

76. D. Buttermer, PLG Inc., 191 Calle Magdalena, Suite 240, Encinitas, CA 92024

77. James Metcalf, Stone and Webster, 245 Summer Street, MS 245-2, Boston, MA 02107

78. John Conine, G. E. Knolls Atomic Power Laboratory, Box 1072, D2-221, Schenectady, NY 12501

79. J. Sugimoto, Japan Atomic Energy Research Institute, Tokai-mura, Naka-gun, Ibaraki-ken, 319-11, Japan

80. Hee-Dong Kim, Nuclear Safety Division, Korea Advanced Energy Research Institute, P.O. Box 7, Daeduk Danji, Taejon 305-353, Korea

81. Kenji Takumi, Nuclear Power Engineering Center, Fujitakanko Building, 17-1, 3-Chrome, Toranomon, Minato-Ku, Tokyo 105, Japan

82. J. W. Wolfe, Westinghouse Bettis Atomic Laboratory, P.O. Box 79, ZAP 34N, West Mifflin, PA 15122

83. S. Inamati, General Atomics, P.O. Box 85608, San Diego, CA 92138-5608

84. M. Kazimi, Massachusetts Institute of Technology, Nuclear Engineering Department, 77 Massachusetts Avenue Cambridge, MA 02139

85. N. Tudreas, Massachusetts Institute of Technology, Nuclear Engineering Department, 77 Massachusetts A enue, Cambridge, MA 02139

86. E. Stubbe, Belgonucleaire, Department of LWR Fuel, Rue de Champde Mars 25, B-1050 Brussels, Belgium

87. L. A. Simpson, Whiteshell Laboratories AECL Research, Reactor Safety Research Division, Pinawa, Manitoba, Canada ROE 1LO

88. Peter Hofmann, Institute of Materials \& Solid State Research, Kernforschungszentrum Karlsruhe, P.O. Box 3640, D-7500 Karlsruhe 1, Germany

89. Bernhard Kuczera, Nuclear Safety Research Project (PSF), Kernforschungszentrum Karlsruhe, P.O. Box 3640, D-7500 Karlsruhe 1, Germany 
90. G. Petrangeli, Nucleare e della Protezione Sanitaria, Ente Nazionnle Energie Alternative, Viale Regina Margherita, 125, Casella Postale M. 2358, I-00100 Roma A.D., Italy

91. S. I. Chang, Institute of Nuclear Energy Research, P.O. Box 3, Lungtan, Taiwan 325, Republic of China

92. J. Bagues, Consejo de Seguridad Nuckan, SOR Angela de la Cruz No 3, Madrid 28056, Spain

93. A. Alonso, E.T.S. Ingenieros Industriales, Jost Gutierrez Abascal, 2, 28006 Madrid, Spain

94. W. Frid, Statens Karnkraftinspektion, P.O. Box 27106, S-10252 Stockholm, Sweden

95. K. J. Brinkman, Reactor Centrum Nederland, 1755 ZG Petten, The Netherlands

96. Paola Fasoli-Stella, Thermodynamics and Radiation Physics, CEC Joint Research Center, Ispra, I-201020 Ispra (Varese), Italy

97. P. Vaisnys, VATESI, Gediminis Prospect 36, Vilnius, Lithuania

98. S. Elo, Hungarian Atomic Energy Commission, H-1374 Budapest, P.O. Box 565, Budapest, Hungary

99. J. Stuller, State Office for Nuclear Safety, Slezska 9, 120000 Prague 2, Czech Republic

100. S. Kinnersly, UKAEA, Winfrith, Dorchester DT2-8DH, Dorset, England

101. D. Williams, UKAEA, Winfrith, Dorchester DT2-8DH, Dorset, England

102. J. A. Martinez, Consijo de Seguridad Nuclear, Justo Dorado 11, 28040 Madrid, Spain

103. V. Asmolov, I.V. Kurchatov Institute of Atomic Energy, Nuclear Safety Department, Moscow 123182, Russia

104. M. LiVolant, Institut de Protection et de Surete Nucleaire, CEN/FAR - B.P. No 6, F-92265, Fontenay-auxRoses, Cedex, France

105. P. Hosemann, Paul Scherrar Institute, Programm LWR-Sicherheit, CH-5232 Villigen, PSI, Switzerland

106. Y. Yanev, Committee on the Use of Atomic Energy for Peaceful Purposes, 69 Shipchenski, Prokhod Blvd., 1574 , Sofia, Bulgaria

107. J. Misak, Nuclear Regulatory Authority, Slovak Republic, Bajkalska 27, 82721 Bratislave, Solvak Republic

108. A. Meyer-Heine, Cadarache Center for Nuclear Studies, F-13108 Saint Paul-Lez-Durance Cedex, France

109. J. Leveque, DTP/SECC/LESC, Centre d'Etudes Nucleaires de Grenoble, $85 X$ - 38041 Grenoble Cedex, France

110. B. Andre, Service d'Etude du Comportement des Combustibles, Centre d'Etudes Nucleaire de Grenoble, 17 Rue de Martyrs, 38054 Grenoble Cedex 9, France

111. S. Chakraborty, Swiss Federal Nuclear Safety Inspectorate, CH-5232 Villigen - HSK, Switzerland

112. P. Kloeg, N.V. Kema, P.O. Box 9035,6800 ET ARNHEM, The Netherlands

113. L. Bolshov, Russian Academy of Sciences, Nuclear Safety Institute, 52, 8, Tulskaya, Moscow, 113191, Russia

114. E. Cordfunke, Netherlands Energy Research Foundation, P.O. Box 1, 1755 ZG Petten, The Netherlands

115. B. Mavko, Jozef Stefan Institute, Jamova 39, 61111 Lujubljana, Slovenia, Czechoslovakia

116. P. Stoop, Netherlands Energy Research Foundation, P.O. Box 1, 1755 ZG Patten, The Netherlands

117. K. S. Norwood, 8 Appleford Drive, Abingdon, Oxon OX14, 2DA, United Kingdom

118. S. J. Wisbey, B.220, AERE Harwell, Didcot, Oxon OX11 ORA, Jnited Kingdom

119. T. Yamashita, Nuclear Fuel Chemistry Laboratory, Department of Chemistry, Japan Atomic Energy Research Institute, Tokai-mura, Naka-gun, Ibaraki-ken, 319-11, Japan

120. S. Hagen, Bau 601, Kernforschungszentrum Karlsruhe, Postface 3640, D7500 Karlsruhe 1, Federal Republic of Germany

121. M. L. Brown, 15 Barrock St., Thurso Caithness, Scotland KW14 7DB

122. T. Nakamura, Japan Atomic Energy Research Institute, Reactivity Accident Laboratory, Department of Fuel Safety Research, Tokai Research Establishment, Tokai-Mura, Naka-Gun, Ibaraki-Ken, Japan 319-11

123. H. K. Lee, Spent Fuel Storage and Disposal Technology Section, Korea Advanced Energy Research Institute, P.O. Office Box 7, Dae-Danji Choong-Nam, Republic of Korea

124. Y.-C. Tong, Institute of Nuclear Energy Research, P.O. Box 3-6, Lung-Tan, Taiwan, Republic of China

125. A. Nichols, Technology Division, AEE Winfrith, Dorchester, Dorset, England

126. D. Williams, Technology Division, AEE Winfrith, Dorchester, Dorset, England

127. F. C. Inglesias, AECL, Chalk River Nuclear Laboratories, Chalk River, Ontario, KOJ 1JO, Canada

128. R. R. Hobbins, EG\&G Idaho, Inc., P.O. Box 1625, Idaho Falls, ID 83401

129. D. A. Petti, EG\&G Idaho, Inc., P.O. Box 1625, Idaho Falls, ID 83401

130. D. J. Osetek, Los Alamos Technical Associates, Inc., 2400 Louisiana Blvd. N.E., Building 1, Suite 400, Albuquerque, NM 87110.

131. L. A. Neimark, Argonne National Laboratory, 9700 South Cass Ave., Argonne, IL 60439 
132. J. Rest, Argonne National Laboratory, 9700 South Cass Ave., Argonne, IL 60439

133. Y. Y. Liu, Argonne National Laboratory, 9700 South Cass Ave., Argonne, IL 60439

134. K. Y. Suh, Fauske \& Associates, Inc., 16W070 West 83rd St., Burr Ridge, IL 60521

135. D. S. Cox, Chalk River Laboratories, Chalk River, Ontario, Canada KOJ $1 \mathrm{JO}$

136. B. J. Lowis, Department of Chemistry and Chemical Engineering, Royal Military College of Canada, Kinzston, Ontario K7K 5LO, Canada

137. B. R. Bowsher, AEA Technology, Winfrith, Dorchester, Dorset DT2 8DH, United Kingdom

138-387. Given distribution as shown in Category R3 (NTIS - 10) 

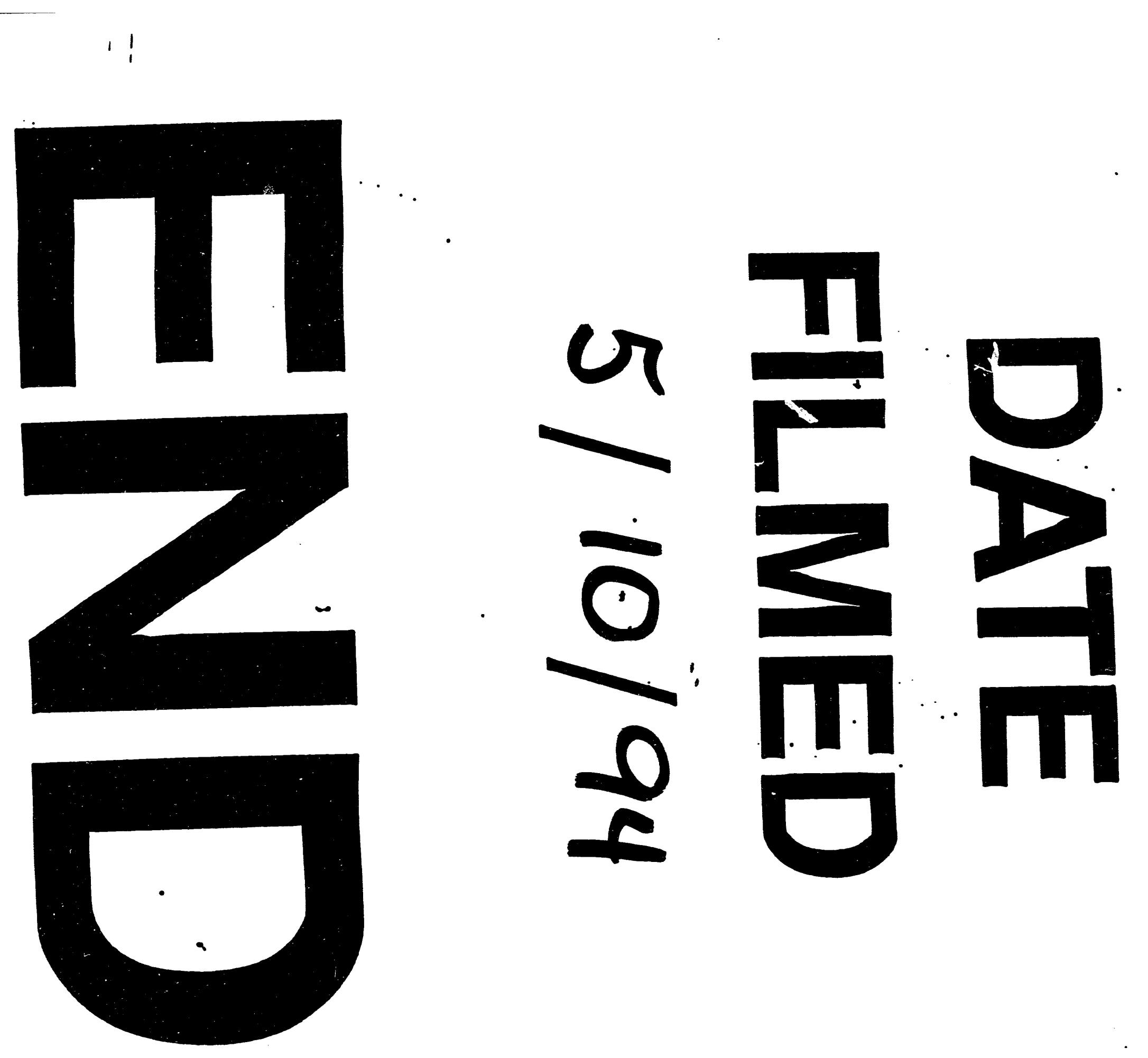


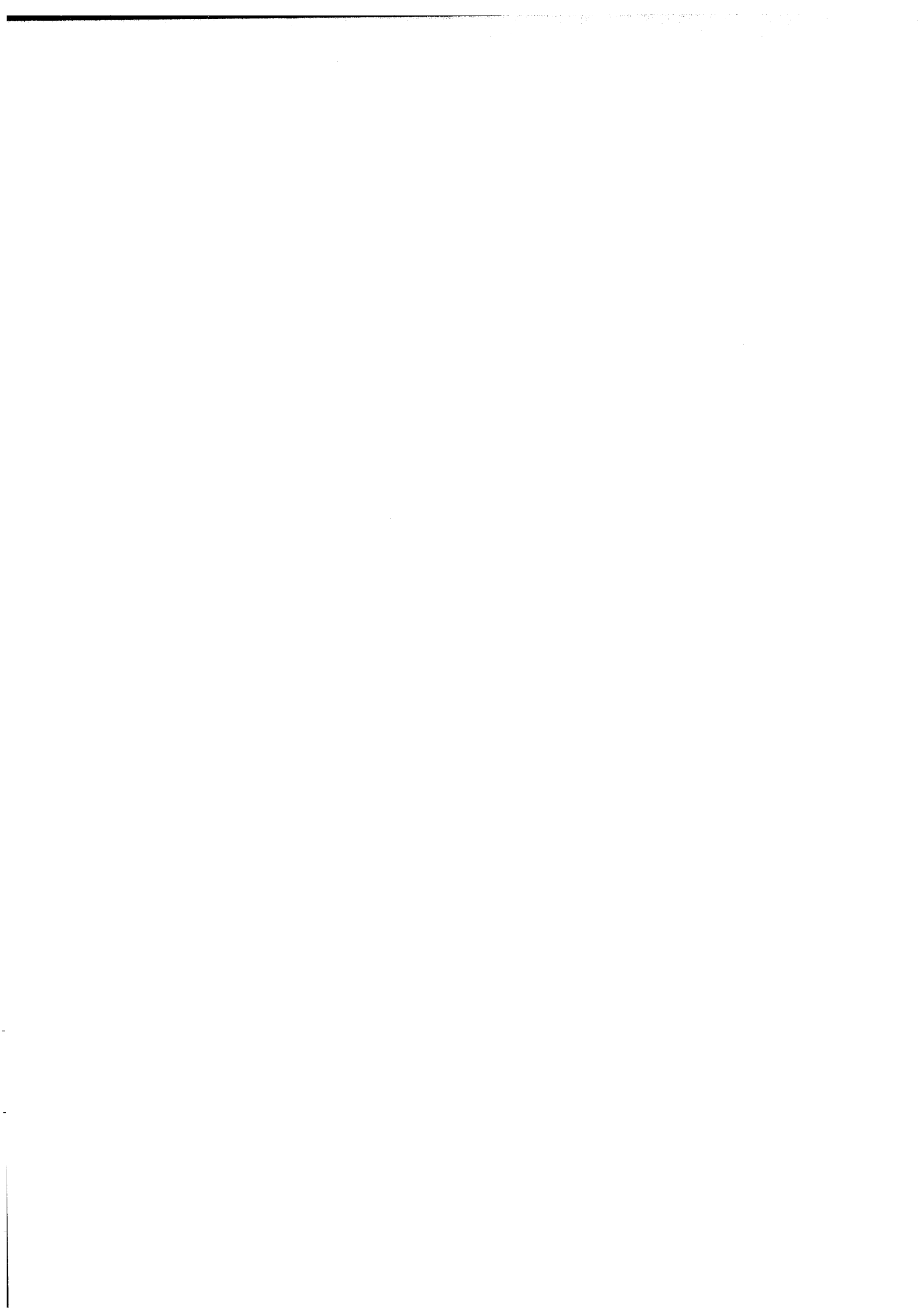

$-$ 